Portland State University

PDXScholar

$1-1-2010$

\title{
Bilingual Spanish-English Speaking 4-Year-Old- Children: English Normative Data and Correlations with Parent Reports
}

Brooke Leann Powers

Portland State University

Follow this and additional works at: https://pdxscholar.library.pdx.edu/open_access_etds Let us know how access to this document benefits you.

\section{Recommended Citation}

Powers, Brooke Leann, "Bilingual Spanish-English Speaking 4-Year-Old-Children: English Normative Data and Correlations with Parent Reports" (2010). Dissertations and Theses. Paper 337.

https://doi.org/10.15760/etd.337

This Thesis is brought to you for free and open access. It has been accepted for inclusion in Dissertations and Theses by an authorized administrator of PDXScholar. Please contact us if we can make this document more accessible: pdxscholar@pdx.edu. 
Bilingual Spanish-English Speaking 4-Year-Old-Children: English

Normative Data and Correlations with Parent Reports

by

Brooke Leann Powers

A thesis submitted in partial fulfillment of the requirements for the degree of

Master of Science

in

Speech and Hearing Sciences

Thesis Committee:

Christina Gildersleeve-Neumann, Chair

Mary Gordon-Brannan

Lynn Santelmann

Portland State University

(C)2010 


\begin{abstract}
Many bilingual Spanish-English preschool aged children are impacted by speech sound disorders; and research has shown that bilingual speech sound systems develop differently than monolinguals'. Research has also shown that, for monolingual English and Spanish speakers, parent reports can be a valid tool for identification and single-word assessments can effectively diagnose speech disorder, yet little, if any, normative data or information about the validity of parent reports as an identification tool exists for bilingual Spanish-English speakers.
\end{abstract}

The purpose of the present study was to create bilingual speech normative data for English single-word assessment scores for percent consonants correct (PCC), percent vowels correct (PVC), and the index of phonetic complexity (IPC). It also sought to determine correlations of speech scores and parent reports, which was done as an extension of Stertzbach's 2005 study with monolingual Spanish speakers.

Fifty-six bilingual Spanish-English 4-year-olds were administered a singleword assessment in English and normative data was generated from the PCC, PVC, and IPC scores. That normative data was correlated with Likert values from the parent surveys to establish the validity of the report as an identification tool, and finally, the disordered scores (as determined by the normative data) were explored in relation to previous suspicion or diagnosis of disorder.

The normative data showed $89 \%$ of speech scores falling within the typical range for both PCC and PVC and 93\% for IPC. Pearson coefficients were computed 
by regression analysis and parent reports were deemed a valid tool for identification based on statistically significant correlations (at the .05 level) for 6 of 10 questions. Previous suspicions of disorder, based on parent report or examiner questionnaire, were $87.5 \%$ and $91 \%$ accurate, respectively, while current diagnosis, based on the presence of an existing Individualized Family Service Plan (IFSP), was 93\% accurate. The results were consistent with previous research showing the prevalence of speech disorder as well as the validity of the parent report. 
Table of Contents

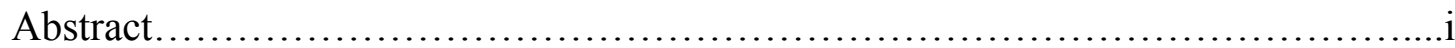

List of Tables.............................................................

List of

Figures................................................................

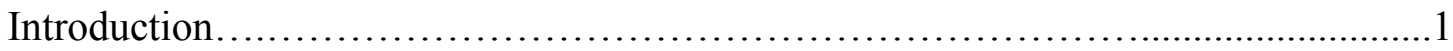

Literature Review...........................................................4

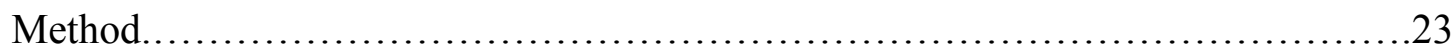

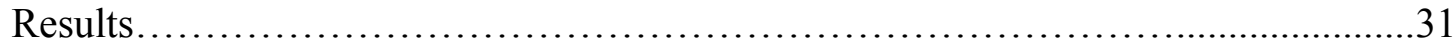

Discussion.........................................................44

Conclusion.......................................................... 53

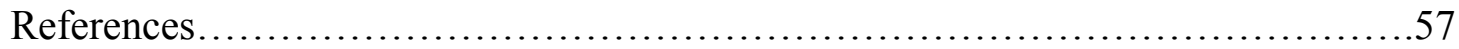

Appendices

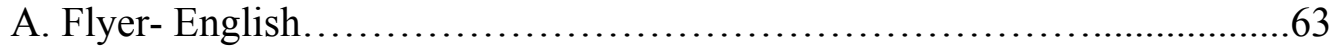

B. Flyer- Spanish................................................64

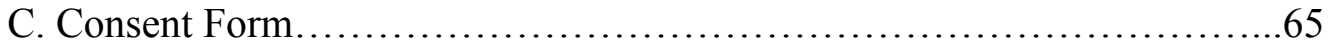

D. Parent Survey (background- English)............................67

E. Parent Survey (background- Spanish) .............................68

F. Parent Survey (language- English) ................................69

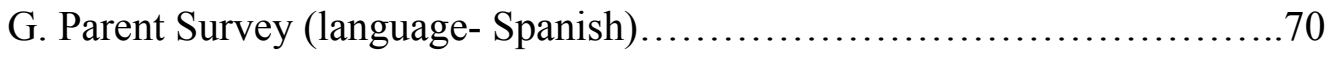

H. Parent Survey (speech- English) ................................. 71 
I. Parent Survey (speech- Spanish).....................................72

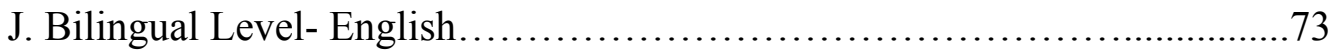

K. Bilingual Level- Spanish...........................................74

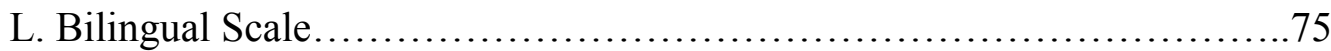

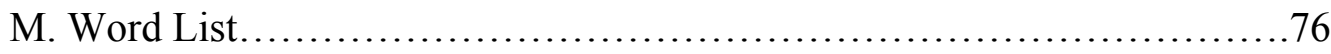

N. Examiner Questionnaire............................................. 77

O. Index of Phonetic Complexity........................................78

P. Pearson Coefficients For All Questions...................................79 


\section{List of Tables}

Table 1

Number and Percentage of Disordered Scores for PCC, PVC, IPC

Table 2

Individual Disordered Scores................................................. 37

Table 3

Disordered Scores and Suspected or Diagnosed Disorder...........................39

Table 4

Pearson Coefficients for Statistically Significant Questions.

Table 5

Statistically Significant Survey Questions.

Table 6

Identification. .50

Table 7

Diagnosis. .51 


\section{List of Figures}

Figure 1

PCC Normative

Data........................................................

Figure 2

PVC Normative

Data....................................................... 34

Figure 3

IPC Normative

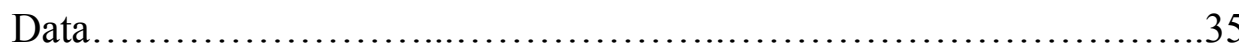


Bilingual Spanish-English Speaking 4-Year-Old-Children: English Normative Data and Correlations with Parent Reports

\section{Introduction}

The estimated incidence of speech sound disorder in preschool-aged children is as high as $10 \%$ to $15 \%$ (Anderson, 2004), hence the need for effective identification and assessment in this age group. Speech sound disorders can negatively affect a child's academic and socio-emotional development. These disorders can, however, can be more successfully treated if identified early. Research has shown that identifying disorders early (preschool or younger) can increase the likelihood of remediation and/or more effective speech treatment (Gillon, 2005). A complete understanding of speech sound development is crucial for effective identification and assessment of speech disorders.

Speech-language pathologists (SLPs) have many resources available to assist in the identification of speech sound disorders in monolingual children, but few, if any, resources are available for bilingual children. SLPs must have linguistically appropriate tests and normative information to assess this population effectively because many bilingual children could be receiving misdiagnoses. While we need these resources for all bilingual children, this study focuses on identifying resources for the largest bilingual population in the United States, Spanish-English bilingual children.

Single- word speech assessments, such as the Goldman Fristoe Test of Articulation (Goldman \& Fristoe, 2000) and the Photo Articulation Test (Pendergast, 
Dickey, Selmar, \& Soder, 1997), have been used to identify disorders in monolingual English-speaking children (Davis, 2005a). Single-word articulation tests efficiently and effectively assess speech sounds. They offer a relatively quick and reliable way to see if a child can produce most of the consonants of English and some consonant clusters. The tests also yield a standardized score, which, when comparing a child's performance with a group of English-speaking age-matched peers, can differentiate between typical and disordered speech. The use of valid standardized tests can result in appropriate diagnosis of speech sound disorders.

While there are standardized tests and normative data for monolingual English and monolingual Spanish speakers, there are none for bilingual Spanish-English speaking children (Goldstein, 2001b). There are, however, according to the 2008 U.S. Census American Community Survey, over 34 million people who speak Spanish in their homes; 53.3\% speaking English "very well" and 46.7\% speaking less than "very well." It is reasonable to estimate that many children of Spanish- speaking parents are bilingual. Bilingual normative data will be helpful in validating standardized measures as well as understanding bilingual development.

SLPs must understand typical bilingual speech development and the crosslinguistic influences of Spanish and English because they can affect the speech accuracy of bilingual children. Developmental differences and cross-linguistic influences possibly explain the under-identification and over-identification of speech sound disorders in bilingual children. Currently, information on monolingual 
development is often used for bilingual children, likely resulting in frequent misdiagnoses of children within this population (Yavas \& Goldstein, 1998).

In addition to single-word assessments, parent surveys could be a valuable tool for speech disorder identification. Research has shown the effectiveness of parent surveys in disorder identification of both English and Spanish speakers; however, current data exist only for monolingual speakers (e.g., Stertzbach, 2005; Thal, O'Hanlon, Clemmons, \& LaShon, 1999). Given the lack of normative data and appropriate assessments for bilingual Spanish-English speakers and the fact that most SLPs don't share both languages of their bilingual clients, parent reports could be an invaluable way of obtaining speech information about bilinguals. Information about the validity of parent reports for bilinguals can also help SLPs and other professionals understand bilingual speech development and possibly reduce the number of misdiagnoses.

This study addresses the needs for understanding speech sound development in bilingual children for the purposes of differentiating typical and atypical development. It does so by analyzing the speech sound accuracy scores of English single-word assessment samples from bilingual Spanish-English 4-year-olds to determine typical and atypical performance. Correlations between the speech accuracy scores and parent reports are calculated to establish the validity of parent reports in identification of speech sound disorders based on the bilingual normative data obtained through the single word assessment samples. Research have shown that while the percentages of atypical scores for bilingual children are similar to monolinguals (Anderson, 2004), 
the ranges of scores and consequent cut-off scores are lower than those of monolingual Spanish speakers (Stertzbach, 2005). Additionally, the parent survey is shown to be a valid tool for speech sound disorder identification, evidenced by the fact that the majority of survey questions have statistically significant correlations with consonant accuracy scores. There are not statistically significant correlations with vowel accuracy scores.

\section{Literature Review}

To effectively identify and diagnose speech sound disorders in bilingual Spanish-English speaking children, we must understand how typical bilingual children

develop their speech sound systems in order to discriminate a speech sound difference from a disorder within this population. This study obtained speech sound system normative data, commonly used for monolinguals, for Spanish-English bilingual preschoolers using a single-word identification task. Additionally, the normative data from the single-word assessment was used to examine the accuracy of the bilingual children's parent reports to see how well this screening tool identifies typical or atypical speech when compared to actual speech scores. Lastly, the bilingual normative data afforded an exploration of the accuracy of some current methods of designating a bilingual child's speech sound system as being disordered.

\section{Bilingual Sound System Development}

The bilingual speech sound system has been shown to develop similarly to a monolingual speech sound system; however, research suggests that the two types of systems are not identical. 
Developmental differences. Accurate identification and diagnosis of speech sound disorder in bilingual speakers is difficult because of developmental differences and cross-linguistic influences that can affect speech sound accuracy and word complexity scores. These differences possibly lower accuracy and complexity scores and may make a bilingual child's speech appear delayed or disordered when compared to a monolingual child's speech.

Phoneme acquisition. One difference in bilingual speech sound development is the length of time required to master all sounds (Vihman, 2002). Likely, bilingual Spanish-English speakers do not always have the same age of onset and mastery of English sounds as monolingual English-speaking children.

Research shows that bilingual children develop language through an amalgamated system, rather than perfecting the sounds and rules for just one language. Subsystems (such as voicing contrasts) have been shown to take longer to master (Vihman, 2002). The difference in speech sound acquisition times for bilinguals may be due to the increased number of total sounds, from two languages, to acquire as well as the cognitive load of categorizing language specific phonemes. For example, the child must understand the allophonic sounds in a given language and which carry meaning and need to be produced in a specific manner (Vihman, 2002). Exposure to and speaking time in each language has also been cited as an explanation for bilingual children's speech showing a different developmental pattern (Dodd, Holm, \& Wei, 1997).

Differences in bilingual vowel acquisition. The Spanish language 
contains 5 vowel phonemes while English has 11 . In a study by GildersleeveNeumann, Pena, Davis, and Kester (2009), single word speech samples were collected in Spanish from 6 children, who were predominantly exposed to Spanish in the home prior to the start of preschool, at the start of regular English exposure in preschool, and again at the end of the school year. Vowel errors increased over the 8-month project for all 6 bilingual participants. The addition of unshared English vowels to the amalgamated system possibly could have been responsible for the increased number of vowel errors. The participants may have been using their previously acquired vowel production positions (tongue height and front/back orientation, jaw position) inaccurately when attempting to produce the new English vowels.

Spanish and English have more unshared vowels than unshared consonants. Thus, vowel acquisition in bilingual speakers could take longer than in monolinguals and a bilingual speech sample may have a higher number of vowel accuracy errors than a monolingual speech sample.

Cross-linguistic influences. There are many other ways that the speech sound system development of bilingual speakers differs from that of monolinguals. Research shows that cross-linguistic influences between Spanish and English can create speech production errors that occur with different frequencies and in different ways than monolingual speech production errors. These errors could be mistaken for disorders. Phonological error patterns such as cluster reduction, initial consonant deletion, reduplication, weak syllable deletion, final consonant deletion, and epenthesis could be present in a child's speech as a result of a still developing dual 
phonotactic rule system. Two sets of phonological rules affecting one another could reduce a child's overall accuracy (Dodd et al., 1997; Goldstein, Fabiano, \& Washington, 2005; Holm. \& Dodd, 1999). Error patterns, such as substitutions, from one language could transfer to and influence the other language (Yavas \& Goldstein, 1998). These substitutions, when combined with the previously mentioned phonological error patterns, are often uncommon and considered atypical when compared to monolinguals and could affect speech accuracy, leading to inappropriate speech disorder diagnoses.

Bilingual speakers have also demonstrated differences in types of speech sound substitutions. A study by Barlow in 2001 examined one Spanish error pattern and its transference to English in order to fully understand characteristics of a fully developed system. The researcher used single-word repetitions in Spanish and English from 4 Spanish-English bilingual children aged 2-4 years whose primary language was Spanish who were part of a larger study. The results showed that Spanish speaking children commonly substitute [l] for $/ \mathrm{r} /$, as in [klus] for $/ \mathrm{krus} /$, rather than the typical English substitutions of $[\mathrm{w}]$ for $/ \mathrm{d} /$ and the schwa in rhotic vowels. The bilingual Spanish-English child could make either of those substitutions, but when the child speaks English, this difference in substitution would have a noticeable effect perceptually and may be mistaken for an atypical pattern. Another example of a substitution made by some Spanish-English bilinguals is [l] for the intervocalic / $/$ / (Barlow, 2001). 
Speech sound system substitutions were also found in a 2005 study by Goldstein, Fabiano, and Washington. This study's participants were 15 bilingual children of Puerto Rican descent, aged 5;0-5;5 (years; months) who were separated into three groups based on predominance of language spoken (primarily Spanish, primarily English, or equal Spanish and English as reported by their parents). The participants were administered a single-word assessment in order to analyze and compare the following phonological skills: consonant accuracy, type and frequency of substitutions, type and frequency of phonological patterns, accuracy of various syllable types, and type and rate of cross-linguistic effects. Results indicated that while there were similarities, the bilingual Spanish-English children had different substitution patterns and patterns occurring with different frequencies than the monolingual English or monolingual Spanish children. For example, the bilingual children substituted $[\mathrm{k}]$ or $[\mathrm{v}]$ for $/ \mathrm{f} /$, which was different than the monolingual Spanish children. The Spanish-English bilingual children substituted [j] for /// which was different than the monolingual English speaking children. The Spanish-English bilinguals' affricates were less accurate than the monolingual English-speaking children while the Spanish-English bilinguals' fricatives were more accurate than the monolingual Spanish-speaking children. The Spanish-English bilinguals exhibited higher percentages of cluster reduction and final consonant deletion yet lower percent occurrence of weak syllable deletion when speaking English. For these reasons, these bilinguals could be erroneously considered atypical compared to either monolingual 
English or monolingual Spanish speaking children and the speech accuracy of the bilingual children could be affected.

Differences in consonant substitutions have been observed in Spanish-English bilingual development. The speech sound errors of aspiration and gliding were cited as examples of one language interfering with another (Shnitzer \& Krasinski, 1996). Other transference examples have included Spanish features during English productions: $/ \mathrm{V} / \rightarrow[\mathrm{b}], / \mathrm{n} / \rightarrow \emptyset, / \mathrm{\lambda} / \rightarrow[\mathrm{r}]$ and $/ \mathrm{J} / \rightarrow\left[\mathrm{t} \int\right]$ and English features during Spanish productions: $/ \mathrm{r} / \rightarrow[\Lambda]$ and $/ \mathrm{r} / \rightarrow[\mathrm{r}]$ (Goldstein \& Washington, 2001).

Bilingual speech samples may contain more errors and thus a decreased accuracy rate when compared with a monolingual speech sample due to phonotactic rule transfer or perceptual differences. An example of phonotactic rule transfer and vowel difference in bilingual Spanish-English development, resulting in decreased English vowel accuracy compared to monolingual English children and later age of acquisition of voiced fricatives, can be found in a study by Amastae (1982). This case study followed the phonological, morphological, syntactic, and pragmatic development of one girl from approximately 8 months through 4 years of age. She lived in bilingual environments first in southern Texas, then in Colombia from the age of 25 months to 38 months with limited English exposure, and back to southern Texas after that. Results from this study indicate that although she was appropriately applying rules for both languages by age 26-28 months, and by $28-30$ months, her Spanish stress acquisition and English phonology were well developed, her vowels still sounded Spanish at 30 months and she developed voiced fricatives later than 
monolinguals of both languages. Vowel inaccuracies and late fricative development compared to age-matched monolingual English speaking peers would result in a lower overall accuracy rate.

\section{Accurate Diagnosis}

An understanding of the typical speech development of bilingual children has been helpful in accurately diagnosing disorders in bilingual children. Holm, Dodd, Stow, and Pert (1999) examined the speech systems of 8 Mirpuri-English, 17 PunjabiEnglish, and 10 Urdu-English bilingual children ages 4;8 to 7;5 years. They analyzed the groups' speech sound accuracy to understand typical development for these bilinguals with regard to phonological processes, phoneme acquisition, and percentage of consonants correct (PCC). Findings revealed that, overall, the children did not keep their phonological systems separate and that they didn't acquire phonology in the same manner as monolinguals of any of the languages. The researchers then used this information to examine the results of two children (one Urdu-English speaker and one Mirpuri-English speaker) who were suspected of having a speech sound disorder. The children were each assessed in English via the South Tyneside Assessment of Phonology (STAP-2, Armstrong, \& Ainley, 1992). Results showed that the UrduEnglish bilingual child exhibited phonological processes (backing, final-consonant devoicing, not releasing final consonants and final consonant deletion, stopping, and assimilation) that were consistent with the typically developing Urdu-English bilingual children. She had acquired all of the English phonemes except for voiced / $\partial /$ and voiceless $/ \theta /$, and had $84 \%$ PCC. All of these errors were age appropriate for Urdu- 
English bilingual children and she was designated as typically developing for an UrduEnglish bilingual child. The second child, the Mirpuri-English bilingual speaker, showed inconsistent phonological patterns such as stopping, initial consonant deletion, final consonant deletion, cluster reduction, gliding, glottal stop substitutions, voicing, assimilation, fronting, and vowel distortions and had 38\% percent of consonants correct. These errors were not age appropriate or consistent with typically developing Mirpuri-English bilingual peers and the child was correctly identified as being disordered.

The bilingual speech development data from the Holm et al., (1999) study was used to create typical speech accuracy percentages and error patterns for MirpuriEnglish, Punjabi-English, and Urdu-English speaking children. The researchers described the bilingual participants' scores as typical or disordered, based on their comparison to typical scores, in the same manner in which professionals utilize existing normative data to determine typical and atypical speech scores for monolingual speakers. The current study created speech accuracy and complexity normative data for Spanish-English bilingual speakers, and the participants' scores were compared to these data to determine if the child has typical or disordered speech.

Normative data. Valid normative data are needed to reflect typical speech sound development for bilingual Spanish-English speakers. While existing normative data accurately represent monolingual speakers of English and Spanish, bilingual Spanish-English children are not represented by monolingual English or monolingual Spanish norms. As Restrepo and Silverman (2001) stated “...the use of standardized 
scores is not required for children for whom there are no such validated measures. In fact, the use of such measures may violate children's rights to an appropriate and unbiased assessment" (p. 391). Bilingual normative data can reduce over-diagnoses of speech sound disorders in this population (Restrepo \& Silverman, 2001) and can result in accurate diagnoses of disorder (Holm et al., 1999).

Valid speech sound assessment normative data. To understand speech sound disorders, clinicians determine if children's scores fall within the average range for their age. The normative data for a valid speech sound assessment should contain speech accuracy scores from a large sample of typically developing children. Single-word assessments such as the Goldman Fristoe Test of Articulation-2 (GFTA-2, Goldman and Fristoe, 2000) include children in their normative samples from a variety of ages and genders, ethnicities, United States regions, and parental education levels. For most assessments, all of the children are monolingual English speakers. There are limited samples of normative data available for monolingual Spanish speakers in assessments such as the Spanish Preschool Language Scale-4 (Zimmerman, Steiner, \& Pond, 2002), primarily a receptive and expressive language assessment that also addresses single words in a screening section.

\section{Single-Word Assessments}

Single-word assessments, commonly and frequently used for understanding speech development, have been used for more than 30 years (e.g., Goldman Fristoe Test of Articulation-2, Goldman \& Fristoe, 2000; Photo Articulation Test-3, Pendergast, Dickey, Selmar, \& Soder,1997). Utilized widely in schools, clinics, and 
private practices across the country, these assessments are designed for ease of administration and serve as an efficient way of obtaining articulation and phonological information from monolingual children because they can be administered and scored quickly and easily (Schraeder et al., (1999).

The single-word repetition format allows the child to produce a large number of consonants and various cluster combinations. This format also allows the clinician to hear the child produce these sounds in different word positions and in words of different lengths. Clinicians can then analyze the child's utterances to determine the accuracy when compared to adult productions. This analysis can also identify phonological error patterns, another widely used measurement for determining typical or atypical speech sound development. During phonological development, all children's speech will contain error patterns; however, it is important to know whether those patterns are common or uncommon (as determined for various languages) because studies have shown that children who have a "suspected" speech disorder often exhibit uncommon or a higher rate of error patterns (Yavas \& Goldstein, 1998).

Assessment score applications. Single-word assessment scores can assist in determining eligibility for services, as indicated in the Clinical Assessment of Articulation and Phonology (CAAP), (Secord \& Donohue, 2002), GFTA-2 (Goldman \& Fristoe, 2000), and PAT-3 (Pendergast, et. al., 1997) manuals. The normed scores for these assessments are grouped according to age and gender, based on age-based standard scores, and have a mean of 100 and a standard deviation of 15 . These normative data create the possibility of comparing the results of one assessment tool 
with other assessments that use a similar distribution. A clinician describes how many standard deviations (increments of 15 either above or below 100) away from the mean a given child's score falls. Early intervention organizations, schools, and insurance companies decide the number of standard deviations below the mean that children's scores must fall (typically 1.5 or 2) before considering them as having a speech disorder and thus eligible to receive speech treatment services.

Single-word assessments and bilingual speakers. Some singleword assessments, inaccurately, claim to be appropriate for preschoolers from multicultural backgrounds. As stated previously, the United States Census 2008 American Community Survey states that over 34 million people speak Spanish in their homes; it is reasonable to estimate that many of those speakers as well as their children are bilingual. The CAAP manual noted that it is designed to assess English articulation and phonology and cautions users about administering it to children from "culturally and linguistically diverse" backgrounds. It explains that the variability in those children's responses could influence the entire assessment process as well as affect diagnostic decisions. The vocabulary selection, speech sounds tested, and length and shape of the target words used in a monolingual assessment often do not accurately reflect a bilingual child's abilities. This could be due to the unique process of developing a speech sound system that includes two languages, differences in sound development, and cross-linguistic influences.

Speech accuracy measurements. Single-word assessments can provide information about speech sound accuracy and error patterns. Accuracy and 
complexity can be measured by percent consonants correct (PCC) and percent vowels correct (PVC). This study uses PCC and PVC (along with complexity scores that will be discussed below) to compile normative data as well as determine correlations with parent surveys.

PCC and PVC measure the frequency and number of consonant and vowel error occurrences, (Goldstein, 2001b; Yavas \& Goldstein, 1998). Clinicians can compare these scores to normative data to determine if a child's speech is typical as well as describe the level of severity if found to be disordered. These accuracy measures have been used frequently to study monolingual children's speech productions. Accuracy measures have also been used in some research on bilingual children. Goldstein and Washington (2001) used PCC as an evaluative measure in their 2001 study to compare Spanish-English bilingual speakers' English and Spanish productions. They compared the Spanish-English bilinguals' PCC scores in Spanish and English with PCC scores from monolingual speakers of each language. The PCC results illustrated the similarities and differences in phoneme accuracy between bilingual and monolingual speakers. Although PCC for manner was slightly higher in English (96.2\%) than in Spanish (90.6\%), the participants demonstrated relatively high PCC overall and their PVC scores in both languages were similar as well $(98.3 \%$ in English and 99.5\% in Spanish).

Another example of PCC use can be found in a study by GildersleeveNeumann, Kester, Davis, and Pena (2008). This study used PCC as an evaluative measure for comparing speech accuracy between groups of 3 and 4-year-old speakers 
who were either from monolingual English or bilingual Spanish-English backgrounds to ascertain how much children's home ambient language affected their speech accuracy. Results of this longitudinal study indicated that at the earliest point of speech measurement, all three groups (irrespective of language background) had acquired most of the sounds necessary to produce one word utterances as was developmentally appropriate. Months later, the children with the most English exposure produced fewer errors, but all three groups showed increased improvement in speech accuracy, suggesting that eventually all groups would achieve an adult English language system.

Consonant and vowel accuracy scores can provide information beyond severity of disorder and intelligibility. A study by Stertzbach in 2005 showed a high correlation between parent reports of Spanish speaking children and scores on a single-word articulation test (measuring PCC and PVC). The participants were 24 Spanish-speaking children ages 3:0 to 4:11 who were all in Spanish-only classrooms. Each participant was administered a Spanish single-word assessment and the PCC and PVC scores from those tests were compared to their parent's surveys. The parent surveys utilized a Likert rating scale and parents rated their child's speech in a series of questions designed to provide a wide range of communication situations. When the articulation assessment scores were compared to the parent survey rating scores, "statistically significant correlations between the information reported by the parents and articulation tests" (p. 31) were found. There were 3 of 10 statistically significant correlations for PCC and 6 of 10 statistically significant correlations for PVC. This 
confirmed that parent reports could provide an effective initial step in identifying disorders in monolingual Spanish speaking children.

The above-mentioned studies suggest that rates of PCC and PVC are good measures of accuracy for understanding bilingual children's speech sound development, and may provide a descriptive and helpful measure of a child's intelligibility.

Speech complexity measurement. In addition to measuring accuracy related to the phonemes in target words, determining the complexity of sounds and words that a child produces provides valuable data. Whole word productions can be measured using indices such as the Phonological Measure of Language Utterances (Ingram, 2002) and the Index of Phonetic Complexity (IPC, Jakieski,1998), the latter of which is used in this study.

Children universally produce simpler sounds early in development such as stops, nasals, glides, and sounds produced anteriorly in the mouth (Aldridge,1991); and these simpler sounds are more frequently produced by children who have speech sound disorders. As children mature with their phonological systems, they produce more complex sounds with greater accuracy, with the variety of complex sounds varying by language environment (Stoel-Gammon, 1998). A complexity measure, such as IPC, intended to determine the complexity of sounds and sound combinations in words that children are producing, is a pertinent measure for bilingual speakers because the bilingual speech system development and phonetic complexity levels follow a slightly different course than monolingual development. IPC scores are 
currently being calculated in other research for monolingual English speakers and, eventually, bilingual IPC scores should be compared with scores from age-matched bilingual speakers. An IPC analysis for a bilingual speaker could provide a more complete picture of the child's system with fewer language specific biases such as word length and shape. Additionally, individual children would receive credit for their ability to produce sounds or syllables, which may not be relationally accurate in English, but nonetheless represent their speech sound repertoire. The bilingual IPC scores from this study will provide information regarding speech production complexity levels for this population that will in turn contribute to a greater understanding of normative development.

A study by Howell, Au-Yeung, Yaruss, and Eldridge (2006) used IPC as a measure of speech production complexity to analyze phonetic difficulty and stuttering in English spontaneous speech. Another study by Howell and Au-Yeung (2007) utilized IPC scores when examining factors involved in stuttering by Spanish speakers. These two studies validated the use of IPC as a measure of complexity for both Spanish and English.

As stated in the previous sections, bilingual Spanish-English speakers develop differently from monolingual speakers, yet little, if any, valid normative data exist to adequately represent them. For these reasons, accurate speech sound system disorder identification and diagnosis proves challenging in the bilingual Spanish-English population. 


\section{Parent Reports}

As previously stated, many bilingual children aren't benefiting from early identification. One reason for this could be that a sensitive screening tool, such as a parent report, does not exist for bilingual Spanish-English speaking children.

Identification and assessment of speech sound disorders in bilingual children can be an especially difficult task given that the majority of SLPs are monolingual English speakers. Due to the lack of standardized assessments for bilingual speakers, SLPs often obtain language samples or use informal criterion-based testing in English. The lack of speech system developmental normative data available for bilingual children, however, makes the information gained from these types of assessments difficult to analyze and determine if the bilingual speech system is typical or disordered. We need a reliable source for information regarding typical speech of bilingual children. Families could provide this information through the use of parent reports, sharing their unique knowledge about their child's speech with SLPs.

The use of parent reports has been shown to be an effective tool in the identification of speech sound disorder in children (Stertzbach, 2005; Thal et al., 1999). Parent reports for monolingual English and Spanish-speaking children will be discussed in this section as well as the need for information about the validity of parent reports with bilingual Spanish-English speakers.

Effective measures of disorder in English-speaking children have been found in parent reports. Thal et al. (1999) examined parent report via the MacArthur Communicative Developmental Inventory (Fenson et al., 1993) as a means of assessing 
children's language production in two different experiments. In the first experiment, they compared the MacArthur CDI parent information with children's scores from the Expressive One Word Picture Test (Gardener 1990) and an experimental picture identification measure, the Memory for Sentences subtest of the Stanford-Binet Intelligence Scale (Thorndike, Hagen, \& Sattler, 1986). The second experiment compared the MacArthur CDI parent information with children's scores from the Preschool Language Scale-Revised ( $4^{\text {th }}$ ed.) (Zimmerman, Steiner, \& Pond, 2002) and analyses of spontaneous language and communication samples. The results of both experiments indicated that the parent report was a valid tool in assessing speech and language abilities. Although the studies were primarily concerned with language, possibly similar results would be found for speech.

Speech sound disorder identification in Spanish speaking children has been effectively achieved through the use of parent reports. Stertzbach (2005) showed a high correlation between parent reports of Spanish-speaking children and scores on a single-word articulation test (PCC and PVC). In that study, the PVC values of $r=.70$ and PCC values of $\mathrm{r}=.69$ were considered strong positive correlations. The current study will serve as an extension of the Stertzbach (2005) study and will compare parent Likert responses from the same questionnaire used in the previous study to bilingual Spanish-English children's speech production accuracy on a similar singleword articulation assessment and determine the correlation of those scores to the parent reports and thus, the validity of parent reports within the bilingual population. The procedures for this will be discussed in the Methods section. 
Bilingual Spanish-English. Limited information is available about parent surveys for bilingual Spanish-English speaking children. We need more information about the validity of those surveys, how bilingual children perform on English single-word articulation tests, and the relationship between those scores and the responses on parent surveys to fill these gaps in information and begin building effective tools for speech services within this population. Valid screening tools for bilingual Spanish-English speakers are needed because many bilingual children are being misdiagnosed due to ineffective identification and assessment procedures (Yavas \& Goldstein, 1998).

\section{Research Questions}

Speech disorders in children are prevalent, and early identification and assessment are crucial for effective remediation. Single-word assessments, which are fast, measure speech development, and provide normative data and parent reports have both been successfully used with monolingual children. However, this country is not monolingual. Spanish is the second most common language and there are many Spanish-English bilingual children who are not benefiting from early identification and assessment because there are no normative data or screening tools available that adequately represent this population. This study will provide both of these from English single-word assessment samples.

Normative data from the single-word assessment are valuable in discerning typical versus disordered bilingual speech because, based on research reviewed above (Dodd et al., 1997; Gildersleeve-Neumann et al., 2009; Gildersleeve-Neumann et al., 
2008; Goldstein, 2001b, 2004; Vihman, 2002), bilingual speech sound system development does not mirror monolingual development and bilingual speech often contains errors due to cross-linguistic influences that may appear disordered if compared to monolinguals (Amastae, 1982; Barlow, 2001; Dodd et al., 1997; Goldstein et al., 2005; Holm \& Dodd, 1999; Schnitzer \& Krasinski, 1996; Yavas \& Goldstein, 1998).

The research questions for this study are: What are average (typical) speech accuracy and complexity scores of bilingual Spanish-English speaking children for an English single-word articulation assessment? Are the bilingual children's parent reports significantly correlated with the single-word assessment scores, and thus an effective screening tool? Based on the normative data obtained through the singleword assessment used in this study, how accurate are three current methods (parent report, examiner concern, and/or existing IFSP) in identifying and diagnosing bilingual children as having speech disorders?

The hypothesis tested was: There is a correlation between parent report survey responses and the participants' speech accuracy and complexity scores from the single-word articulation test. This hypothesis is supported by research, as reviewed above, showing high correlations between parent reports and assessment results in monolingual English (Thal et al., 1999) and Spanish (Stertzbach, 2005) speakers. Lastly, an exploration of three current methods of identifying and diagnosing disorder in this population will be possible for the first time because of the normative speech 
accuracy and complexity data obtained in this study for Spanish-English bilingual preschoolers.

\section{Method}

This study obtained developmental norms for phonemic accuracy and phonetic complexity on a single-word assessment for 4-year-old bilingual Spanish-English children. Factors such as evaluator concern, parent concern, and the presence of an IFSP for each participant were investigated. The specifics of these measures are described below. In addition, the current study also determined the correlation between parent survey ratings and the accuracy and complexity measures. Accuracy was determined using PCC and PVC. Complexity values were obtained through the index of phonetic complexity (IPC). The survey scores were determined by analyzing responses on a parent survey. All three measures (PCC, PVC, and IPC) from the children's individual assessment were compared to each reply on their parent (s)'s survey.

\section{Participant Recruitment}

All children in this study were participating in a larger scale longitudinal study on bilingual speech development conducted by Christina Gildersleeve-Neumann, $\mathrm{PhD}$. Parents of children who attend Mt. Hood Head Start Programs were mailed a flyer in English and Spanish describing the study (see Appendices A \& B) and a consent form (see Appendix C). The flyer outlined the criteria required for involvement in the study as well as how long the process would take for their child. In addition, parents filled out a survey (see Appendices D, E, F, G, H, \& I) as well as a series of questions 
designed to describe the child's general understanding and use of both English and Spanish (see Appendices J \& K).

Participants. Fifty-six bilingual Spanish-English children participated in this study. The children, ages $4 ; 0$ to $4 ; 11$, were classified as "bilingual level 3" (see Appendix L). In this scale, Level 1 equaled “only English-speaking” and Level 5 equaled "only Spanish-speaking." Level 3 was considered "bilingual SpanishEnglish," with children exposed to each language at least 15 hours per week. Levels 2 and 4 represent fewer than 15 hours weekly exposure to English or Spanish respectively. Some of these children were suspected of having a speech sound disorder prior to the research evaluation. The "suspected disorder" classification was determined by a response by the examiner or parent indicating concern. Two of the participants had an existing Individualized Family Service Plan (IFSP) which indicated that they had already been identified as having a speech sound disorder by a speech-language pathologist prior to this research study.

\section{Materials}

Speech development questions (survey). Each parent completed a series of questions designed to describe their child's speech as a portion of the parent survey (see Appendices H \& I). This section of the survey incorporated questions adapted from existing validated models and was designed to obtain information about potential speech disorders (Gutierrez-Clellen \& Kreiter, 2003; Restrepo, 1998). The survey included questions about the children's speech intelligibility (according to family and/or people outside the home and compared to other children of the same age), the children's ability to pronounce sounds and words, and whether they leave out 
sounds ("ca" for "cat") or change sounds when speaking ("wun" for "run"), whether or not the child appears to be frustrated when speaking, and finally, whether or not the parents and/or other people feel that the child has speech problems. The survey used a Likert scale to quantify responses that were then available for statistical comparisons. The parent's responses to questions on the Spanish version of the survey have been shown to strongly correlate $(r>.90)$ with percent consonants and vowels correct in monolingual Spanish-speaking children (Stertzbach, 2005).

Single-word articulation assessment. Test administrators used a picture-word identification task to measure speech sound production. The pictureword booklet contained approximately 130 pictures corresponding to an English word list (Appendix M). The words were selected to represent culturally- and ageappropriate vocabulary. Some of the words were selected from the English version of the Communicative Development Inventory (Fenson et al., 1993), the Systematic Analysis of Language Transcripts (SALT) normative database, and with consultation with the children's Head Start teachers. The types of words were chosen to elicit a thorough phonemic inventory from each child with all consonant and vowel phonemes of English except /3/ represented in a number of age-appropriate word opportunities. Words of one, two, three, and four syllables were included in an attempt to represent word lengths common to both English and Spanish (which contains many multisyllabic words). This variety of word shapes was thought a better way of assessing the word lengths that bilingual Spanish-English speaking children are exposed to than assessing only words with lengths more common in English or those 
more common in Spanish. The words provided balanced phonetic complexity, including common consonant sequences in all syllable positions. The utterance length of the required responses was either one or two words. Stimuli were presented one at a time on individual 4.25 " $\times 5.5$ " pages of white laminated paper. The pictures were large, colored drawings of the target words.

Recording devices. Examiners used a Tascam DA-PI audio tape recorder equipped with a Sennheiser e815-SP microphone or an Edirol R-09 24-bit WAVE/MP3 recorder to record the participants' responses.

\section{Procedures}

Single-word speech samples. During normal school hours, each child was brought to a quiet room, away from the main classrooms. A single-word speech sample in English was collected and recorded. Administration was typically 10 to 15 minutes in duration. The pictures representing the target words were presented to the participants one at a time. Each child was instructed to say the name of each picture in English. The test examiner used a question, such as "What is this?" upon presentation of each picture. If the child replied with a nontarget word or did not reply, a prompt was allowed. This came in the form of a delayed model, such as "That's a star. What is it?" Because the focus of this assessment was on sound and word production rather than vocabulary naming ability, the examiner was allowed to give a direct model such as "This is a star. Say star," if the delayed imitation did not elicit the target word. Throughout this procedure, the examiner noted which elicitation method yielded the target words (spontaneous, delayed imitation, direct model). 
At the end of the assessment procedure, the examiner also noted the presence of any atypical speech characteristics observed during the data collection and if these characteristics suggested a risk for a possible speech disorder. The examiner noted the percent of and general comments about overall intelligibility, the child's behavior/emotional status, vocabulary and language comments (such as syntax, morphology, semantic relationships, and pragmatics), if the child substituted Spanish words for English vocabulary, and if the examiner felt that the child had a speech delay or disorder or appeared atypical in any way (see Appendix N).

Data transcription. Due to the variability in the graduate student clinicians' language backgrounds and transcription competencies, on-line phonetic transcription was not completed. On-line transcription would have increased the length of the assessment session for the children and could have reduced their ability to perform because of fatigue. After the assessment was complete, the clinician noted the overall intelligibility of the participant.

The data from the bilingual participants were transcribed at a later date by trained Spanish-English bilingual graduate student clinicians in speech-language pathology using narrow phonetic transcription. This included using diacritics such as dentalization, aspirated vs. unaspirated stops, /s/ distortion types, and vowel production by place (e.g., high, low, front, back). The transcription training sessions were designed to allow practice and discussion regarding phoneme and allophonic differences between Spanish and English as well as phonetic differences in speech that may be Spanish-English and/or English-Spanish influenced. In addition, the 
transcribers were trained to use the same phonetic symbols and diacritic markers. The examiners utilized digital video recordings to ensure accurate perception of the responses by the transcribers. To ensure reliability, each transcription was completed by two different trained transcribers. The first person entered the data into the LIPP system and the second person reviewed the transcriptions and commented on any discrepancies. The project manager reviewed all transcriptions, making final decisions on correct data transcription. She agreed with previous transcriptions on $98 \%$ of the phonemes transcribed.

\section{Data Analyses}

Normative analysis. Relational analyses compare the child's productions to the adult (correct) form. They are useful in providing professionals with information about the accuracy of a child's speech, and in this study, were determined by the PCC (Shriberg, Austin, Lewis, McSweeny, \& Wilson, 1997) and PVC. PCC was determined by dividing the number of consonants that were accurately produced by the total number of consonants in the word list and multiplying that number by 100 . PVC was calculated in the same manner as PCC, but vowels were analyzed instead of consonants. The transcribed English responses from the single word assessments were entered into the Logical International Phonetics Program (LIPP) software program (Oller \& Delgado, 2000) for analyses. With this program, analyses were completed for the frequency and average occurrence of PCC and PVC.

Complexity of children's whole words was explored. To obtain this information, the IPC (Jakielski, 1998) was calculated. This was done for each child's 
sample by first assigning a point value to each word according to eight categories (place, manner, vowels, word shape, word length in syllables, singleton place variegation, contiguous consonants, and cluster type) and the point value for production of each sound according to category (see Appendix 0).

Disorder. The group means, ranges, and standard deviations for PCC, PVC, and IPC scores (respectively) were calculated to determine the cut-off score for each measure. The group mean for each score was obtained by summing the sample scores for each measure (PCC, PVC, and IPC) and then dividing each of those totals by the number of sample scores. The lowest and highest sample scores for PCC, PVC, and IPC determined the range for each measure. The standard deviation (SD) value for each measure represented the approximate amount of dispersion among scores. The specific value of $1 \mathrm{SD}$ for each measure was obtained through a statistical equation. For this study, 1.5 SD below the mean was considered disordered.

Utilizing the above-mentioned data from the PCC, PVC, and IPC scores to form a normative range for each measure, information about children whose scores fell at or below the cut-off scores was explored. This was achieved by noting if, for each score below the cut-off, the examiner, and/or parents reported concerns. The presence of an Individual Family Service Plan (IFSP) was also considered. Additionally, children who were identified as possibly having speech delay and/or disorder by one or more of the previously mentioned sources, but had scores above the cut-off score were explored. 
Parent surveys. The parent survey consisted of three sections. Section 1 (see Appendices D \& E) gathered information about the child's development history with questions that addressed language milestones, medical background, and described the child's family system. Section 2 (see Appendices F \& G), the language survey portion, was designed to describe the child's exposure to, practice time, and proficiency in Spanish and English. The final section focused on speech development questions that could potentially illuminate speech delay and/or disorder (see Appendices H \& I). Parents were asked to respond to the 10 questions that were based on previously developed questionnaires (Restrepo, 1998). The parents completed eight responses by circling answers on a 5-point continuum from "never- rarelysometimes-frequently-all the time." The last two questions used a 5-point continuum of "no-probably not-maybe-probably-yes."

Analysis of parent surveys. The parent surveys from each participant were analyzed to allow for comparisons to the single-word assessment PCC, PVC, and IPC scores in order to determine how closely the parents' perceptions of their child's speech correlated with actual performance scores on the single word assessment. This information determined the level of accuracy of parent reports and their potential use as a screening tool for bilingual Spanish-English speaking preschoolers.

The responses to the 10 questions from the parent surveys were assigned a Likert value of 1 to 5. This Likert value for each question from all of the parent surveys was compared to each child's PCC, PVC, and IPC mean scores (respectively). The 
correlations between the survey Likert values and the accuracy and complexity scores were determined.

\section{Results}

Relational and independent analyses were performed to obtain PCC, PVC, and IPC for each participants' speech sample. The single-word assessment scores, grouped by PCC, PVC, and IPC, produced normative data for each measure that determined typical and disordered scores. The participants' designations as typical or disordered were explored with regard to whether or not they had been previously identified as possibly having a speech disorder. Accuracy and complexity scores for PCC, PVC, and IPC for each child were compared to their parents' survey responses by statistical correlation analysis. This was done to determine the relationship between the participants' actual speech production accuracy and their parents' descriptions of their speech. The normative data showed the following percentages of scores within 1.5 SD above or below the mean for each measure: $89 \%$ of PCC scores, $89 \%$ of PVC scores, and $93 \%$ of IPC scores. Nine participants had disordered scores in one or more areas, with four of the nine being previously identified as potentially disordered.

\section{Normative Analysis}

Relational and independent analyses. PCC, PVC, and IPC were calculated for all participants based on their English responses on the single-word articulation assessment. The English word production samples were compared to English adult form (correct productions) to obtain the PCC and PVC for the relational 
analyses. The IPC was calculated based on the types of and combinations of sounds produced per word for the independent analyses. The relational and independent analyses were conducted with the LIPP software program. Each score was then grouped according to measure (PCC, PVC, and IPC) and the data set range, mean, and standard deviation (SD) were determined.

Individual PCC, PVC, and IPC scores. The number of correct consonants or vowels that the participants produced divided by the number of total consonants or vowels from their sample comprised the PCC and PVC scores. The IPC scores were calculated based on the previously mentioned formula assigning number values to sounds or combinations of sounds per word. The score for each participant was an average of all of the words in the word sample produced.

Percent consonants correct. Figure 4-1 shows the range of PCC scores, which was $21 \%$ to $60 \%$. The mean was $49 \%$ with one SD equaling $7.5 \%$. For this study, the cut-off to describe a score as disordered is $1.5 \mathrm{SD}$ below the mean. The PCC cut-off score was $37 \%$ and the percentage of scores within 1.5 SD above or below the mean was $89 \%$. 


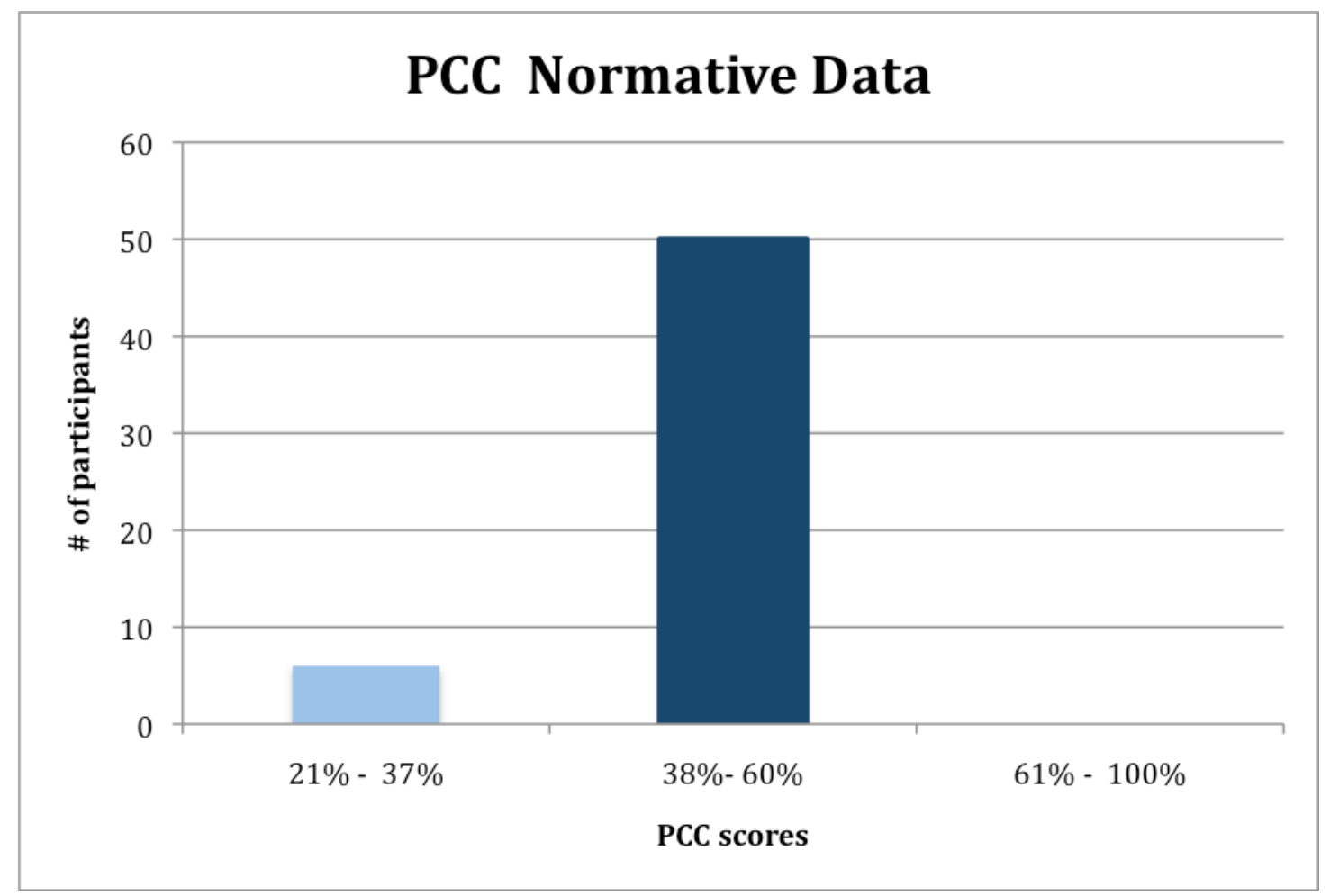

Figure 1. Mean PCC score 49\%. 6 participants had scores (ranging from 21\%-37\%) that were more than 1.5 SD below the mean. 50 participants had scores (ranging from $38 \%-60 \%$ ) that were \pm 1.5 SD about the mean. 0 participants had scores that were more than 1.5 SD above the mean. 
Percent vowels correct. Figure $4-2$ shows the range of PVC scores which was $48 \%$ to $98 \%$. The mean was $76.5 \%$ with one SD equaling $11 \%$. For this study, the cut-off to describe a score as disordered is $1.5 \mathrm{SD}$ below the mean. The PVC cut-off score was $60 \%$. The percentage of scores within $1.5 \mathrm{SD}$ above or below the mean was $89 \%$.

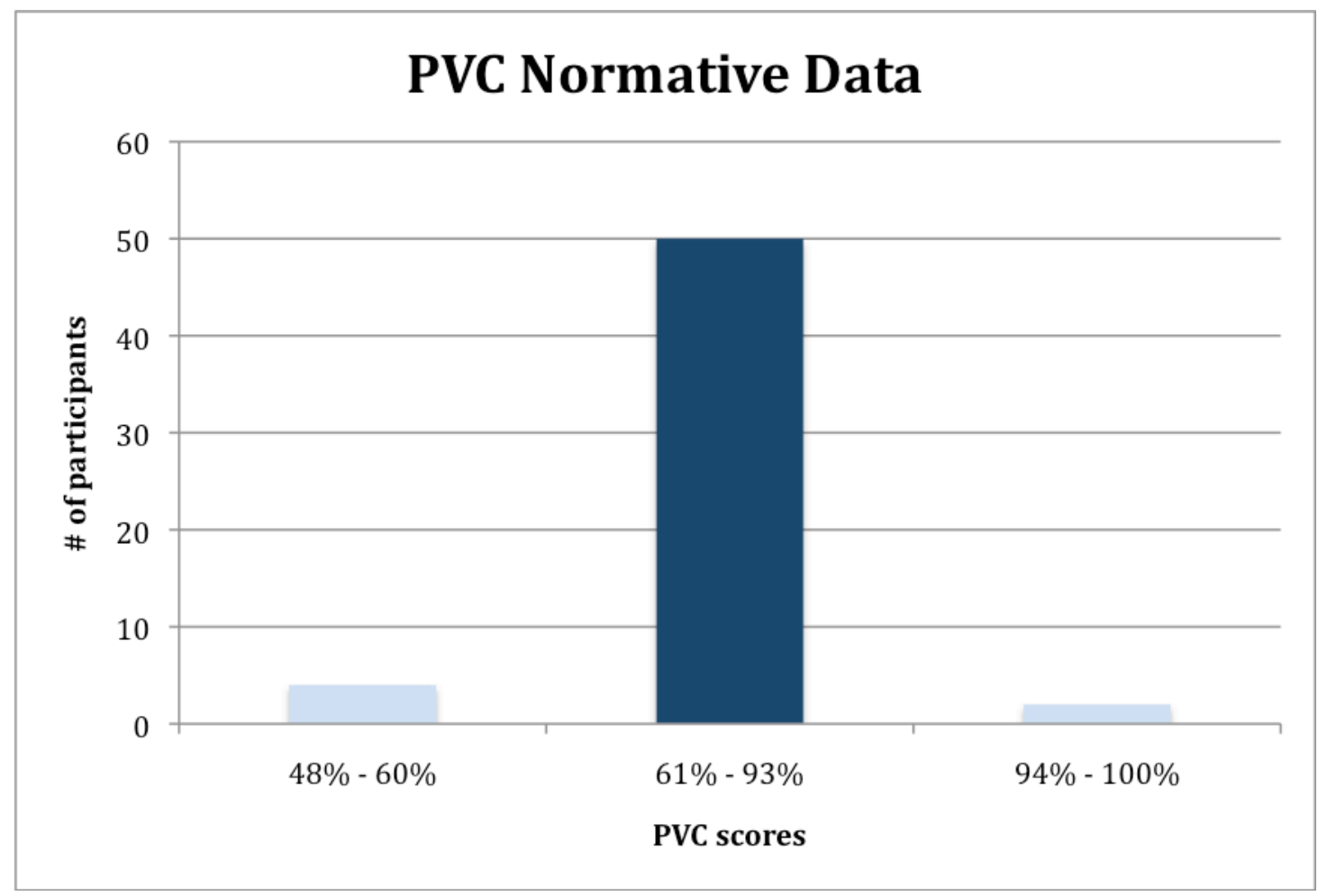

Figure 2. Mean PVC score 76.5\%. 4 participants had scores (ranging from 48\%$60 \%$ ) that were more than $1.5 \mathrm{SD}$ below the mean. 50 participants had scores (ranging from $61 \%-93 \%$ ) that were $\pm 1.5 \mathrm{SD}$ about the mean. 2 participants had scores (ranging from 94\%-100\%) that were more than $1.5 \mathrm{SD}$ above the mean. 
Index of phonetic complexity. Figure 4-3 shows the range of IPC scores the children in this study which was 1.06 to 2.84 . The mean was 2.30 with one SD equaling .40. For this study, the cut-off to describe a score as disordered is $1.5 \mathrm{SD}$ below the mean. The IPC cut-off score was 1.69. The percentage of scores within 1.5 SD above or below the mean was $93 \%$.

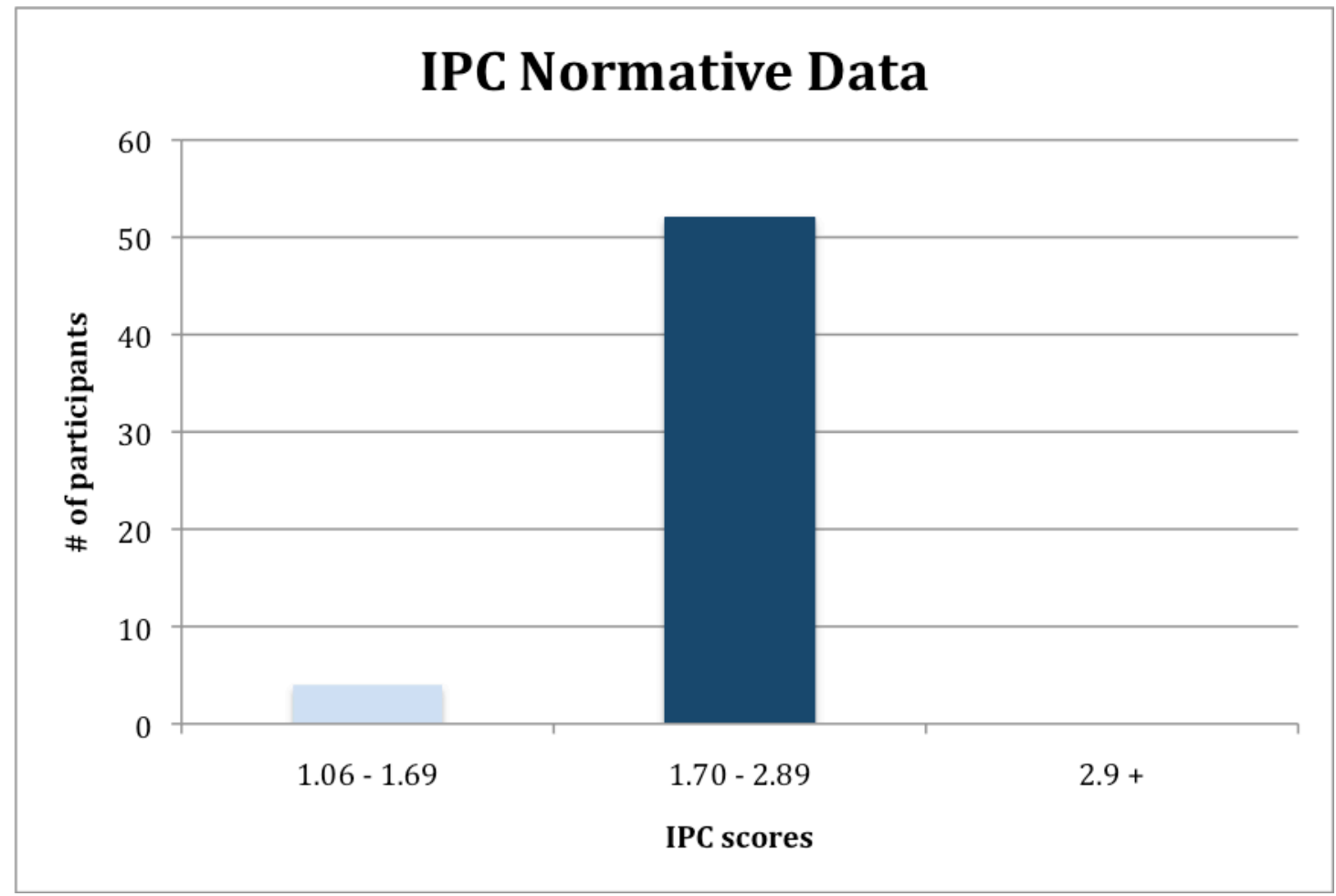

Figure 3. Mean IPC score 2.30. 4 participants had scores (ranging from 1.06-1.69) that were more than $1.5 \mathrm{SD}$ below the mean. 52 participants had scores (ranging from 1.70-2.89) that were $\pm 1.5 \mathrm{SD}$ about the mean. 0 participants had scores more than 1.5 SD above the mean. 


\section{Disorder}

The normative data from the speech accuracy and complexity scores were used to find the frequency and percentage of disordered scores for each measure (PCC, PVC, and IPC) and which combinations of disordered scores occurred.

Disordered scores. The cut-off score for each measure was $1.5 \mathrm{SD}$ below the mean. Each score below the cut-off scores for PCC, PVC, and IPC was considered to be disordered. Table 4-1 represents the score distributions for PCC, PVC, and IPC measures and Table 4-2 shows which measure(s) was disordered for participants with scores below the mean.

Table 1

Number and Percentage of Disordered Scores for PCC, PVC, IPC

\begin{tabular}{lccccc}
\hline & Range & Mean & Cut-off & $\begin{array}{c}\text { \# Disordered } \\
\text { Scores }\end{array}$ & $\begin{array}{c}\% \text { Disordered } \\
\text { Scores }\end{array}$ \\
\hline PCC & $21 \%$ to $60 \%$ & $49 \%$ & $37 \%$ & $6 / 56$ & $11 \%$ \\
PVC & $48 \%$ to $98 \%$ & $76.5 \%$ & $60 \%$ & $4 / 56$ & $7 \%$ \\
IPC & 1.06 to 2.84 & 2.30 & 1.69 & $4 / 56$ & $7 \%$ \\
\hline
\end{tabular}

Note. PCC, PVC, and IPC scores at or below the cut-off scores are considered "disordered." 
Table 2

Individual Disordered Scores

\begin{tabular}{rccc}
\hline & \multicolumn{3}{c}{ Disordered Score } \\
\cline { 2 - 4 } Participant \# & PCC & PVC & IPC \\
2 & $\mathrm{X}$ & $\mathrm{X}$ & $\mathrm{X}$ \\
6 & $\mathrm{X}$ & $\mathrm{X}$ & $\mathrm{X}$ \\
11 & & $\mathrm{X}$ & $\mathrm{X}$ \\
17 & $\mathrm{X}$ & & $\mathrm{X}$ \\
20 & $\mathrm{X}$ & & \\
26 & $\mathrm{X}$ & $\mathrm{X}$ & \\
27 & $\mathrm{X}$ & & \\
28 & & & \\
54 & & &
\end{tabular}

Note. Table 4-2. An "x" denotes a disordered score in PCC, PVC, and/or IPC.

Identification and diagnosis accuracy. Three of the current methods

for speech disorder identification and diagnosis were analyzed to determine their accuracy. The test administrators noted signs of possible speech disorder. Each participant, prior to participating in the study, provided information regarding whether or not there was a concern about speech disorder. This was done by parent report and/or the presence of an existing IFSP.

After administering the single-word assessment for the study, the examiner noted if the child appeared to have a disorder. In the intake questionnaire, the parent had answered "yes," "no," or "maybe" to indicate whether or not the child was suspected of having a disorder. The existence of an IFSP was noted in the child's file as "yes" or "no"; this information was used to indicate that the child was or was not 
diagnosed as having a disorder. An IFSP indicated that a child was referred for a speech and language evaluation and deemed disordered by a speech-language pathologist. The identification and diagnostic accuracy of each of these three sources when compared with actual speech scores will be discussed further in the Discussion section. Table 4-3 shows disordered scores and sources of "concern" that the child may have had a speech disorder. Each participant who had a score falling $1.5 \mathrm{SD}$ below the mean in one or more of the three measures (PCC, PVC, or IPC) was included. Each participant who was identified as possibly having a speech disorder by at least one source (their parent, the assessment examiner, or an existing IFSP) was also included. Responses of "yes" and "maybe" are noted by "X". Responses of "no" are noted by a blank. 
Table 3

Disordered Scores and Suspected or Diagnosed Disorder

\begin{tabular}{|c|c|c|c|c|c|c|}
\hline \multirow[b]{2}{*}{ Participant } & \multicolumn{3}{|c|}{ Disordered Scores } & \multicolumn{3}{|c|}{ Disorder } \\
\hline & PCC & PVC & IPC & Parent & Examiner & IFSP \\
\hline 2 & $X$ & & $X$ & $X$ & $X$ & $X$ \\
\hline 3 & & & & & $\mathrm{X}$ & \\
\hline 5 & & & & $X$ & & \\
\hline 6 & & $X$ & & & & \\
\hline 11 & $\mathrm{X}$ & & $\mathrm{X}$ & $\mathrm{X}$ & $\mathrm{X}$ & \\
\hline 17 & & $\mathrm{X}$ & & & & \\
\hline 19 & & & & $\mathrm{X}$ & & \\
\hline 20 & $\mathrm{X}$ & $\mathrm{X}$ & $\mathrm{X}$ & $\mathrm{X}$ & $\mathrm{X}$ & $\mathrm{X}$ \\
\hline 26 & $\mathrm{X}$ & & & & & \\
\hline 27 & $\mathrm{X}$ & & $\mathrm{X}$ & & $\mathrm{X}$ & \\
\hline 28 & $X$ & & & & & \\
\hline 36 & & & & $\mathrm{X}$ & $\mathrm{X}$ & \\
\hline 51 & & & & $X$ & $X$ & \\
\hline 54 & & $\mathrm{X}$ & & & & \\
\hline
\end{tabular}

Note. See text above for definitions of Parent Concern, Examiner Concern, and Existing IFSP.

\section{Correlations}

Correlations between speech accuracy and complexity scores and survey responses were calculated in order to determine whether or not the parent survey is a valid screening tool for the bilingual Spanish-English pre-school population.

Regression analysis was done to obtain the Pearson coefficient for each measure on each question (see Table 4-4). The range of statistically significant PCC correlations was +.313 to +.444 with a mean of +.366 . The range of statistically significant IPC 
correlations was +.273 to +.393 with a mean of +.336 . PVC did not have any statistically significant correlations. One factor to consider when interpreting the correlations is that question number 10 was not included in the analysis because all of the responses were 5 on the Likert scale, suggesting that the question was not transparent enough to produce more authentic response variety. Also, two parents did not answer one of the questions. 
Table 4

Peasrson Coefficients for Statistically Significant Questions

\begin{tabular}{|c|c|c|c|c|c|c|}
\hline \multirow[b]{2}{*}{ Questions } & \multicolumn{3}{|c|}{$\mathrm{PCC}$} & \multicolumn{3}{|c|}{ IPC } \\
\hline & significance & $\mathrm{r}$ & $\mathrm{r} 2$ & significance & $\mathrm{r}$ & $\mathrm{r} 2$ \\
\hline $\begin{array}{l}\text { 1. Is your child's } \\
\text { pronunciation difficult } \\
\text { to understand? }\end{array}$ & 0.000 & $\begin{array}{l}+.444 \\
\text { (positive } \\
\text { moderate) }\end{array}$ & $19.7 \%$ & 0.002 & $\begin{array}{c}+.393 \\
\text { (positive } \\
\text { moderate) }\end{array}$ & $15.4 \%$ \\
\hline $\begin{array}{l}\text { 2. In comparison to } \\
\text { other children his/her } \\
\text { age, do you think your } \\
\text { child is difficult to } \\
\text { understand? }\end{array}$ & 0.015 & $\begin{array}{c}+.319 \\
\text { (positive } \\
\text { moderate) }\end{array}$ & $10.2 \%$ & 0.007 & $\begin{array}{c}+.353 \\
\text { (positive } \\
\text { moderate) }\end{array}$ & $12.5 \%$ \\
\hline $\begin{array}{l}\text { 3. Do other people } \\
\text { think your child is } \\
\text { difficult to understand? }\end{array}$ & 0.014 & $\begin{array}{l}+.320 \\
\text { (positive } \\
\text { moderate) }\end{array}$ & $10.2 \%$ & 0.016 & $\begin{array}{c}+.315 \\
\text { (positive } \\
\text { moderate) }\end{array}$ & $9.9 \%$ \\
\hline $\begin{array}{l}\text { 5. Does your child have } \\
\text { problems producing } \\
\text { certain sounds? }\end{array}$ & 0.018 & $\begin{array}{c}+.313 \\
\text { (positive } \\
\text { moderate) }\end{array}$ & $9.8 \%$ & 0.040 & $\begin{array}{c}+.273 \\
\text { (positive } \\
\text { weak) }\end{array}$ & $7.5 \%$ \\
\hline $\begin{array}{l}\text { 6. Does your child } \\
\text { leave out sounds when } \\
\text { he/she speaks? For } \\
\text { example, saying "ca" } \\
\text { for "cat", or "tar" for } \\
\text { "star?" }\end{array}$ & 0.003 & $\begin{array}{c}+.392 \\
\text { (positive } \\
\text { moderate) }\end{array}$ & $15.4 \%$ & 0.019 & $\begin{array}{c}+.309 \\
\text { (positive } \\
\text { moderate) }\end{array}$ & $9.5 \%$ \\
\hline $\begin{array}{l}\text { 7. Does you child } \\
\text { change sounds when } \\
\text { he/she speaks? For } \\
\text { example, saying "too" } \\
\text { for "shoe" or "wun" for } \\
\text { "run?" }\end{array}$ & 0.001 & $\begin{array}{c}+.409 \\
\text { (positive } \\
\text { moderate) }\end{array}$ & $16.7 \%$ & 0.004 & $\begin{array}{c}+.371 \\
\text { (positive } \\
\text { moderate) }\end{array}$ & $13.8 \%$ \\
\hline
\end{tabular}

Note. Significance level Pearson .05. PVC did not have any statistically significant correlations and is not included in this table. Questions 4,8, and 9 were not significantly correlated for PCC and IPC and are not included on this table. Question 10 is not included because it was not part of the statistical analysis due to identical responses on the survey (see text above for details). See Appendix P for comprehensive correlation table. 
Percent consonants correct. For PCC, 6 of the 10 questions provided statistically significant correlations (see Table 4-5). As described earlier, the range for PCC scores was $21 \%$ to $60 \%$ and the mean was $49 \%$ (see Table 4-1). Question 1 which asked if the parent thought that the way their child pronounced words was difficult to understand had the strongest correlation at +.444 . The second strongest correlation (+.409) was with question 7 which asked whether or not the child changed sounds when speaking.

Percent vowels correct. For PVC, 0 of the 10 questions provided statistically significant correlations with this measure (see Table 4-5). The range for PVC scores was $48 \%$ to $98 \%$ and the mean was $76.5 \%$ (see Table $4-1$ ).

Index of phonetic complexity. For the IPC, 6 of the 10 questions provided statistically significant correlations with this measure (see Table 4-5). The range for IPC scores was 1.06 to 2.84 and the mean was 2.30 (see Table 4-1). Question 1 which asked if the parent thought that the way their child pronounced words was difficult to understand had the strongest correlation at +.393 . The second strongest correlation $(+.371)$ was with question 7 which asked whether or not the child changed sounds when speaking. 
Table 5

Statistically Significant Survey Questions

\begin{tabular}{llll}
\hline Survey Questions & PCC & PVC & IPC
\end{tabular}

\begin{tabular}{lll}
\hline 1. Is your child's pronunciation difficult to understand? & $\mathrm{X}$ & $\mathrm{X}$
\end{tabular}

2. In comparison to other children his/her age, do you think your $\mathrm{X} \quad \mathrm{X}$ child is difficult to understand?

3. Do other people think your child is difficult to understand? $\quad \mathrm{X} \quad \mathrm{X}$

4. Does your child have difficulty pronouncing words?

5. Does your child have problems producing certain sounds? $\quad \mathrm{X} \quad \mathrm{X}$

6. Does your child leave out sounds when he/she speaks? For $\quad \mathrm{X} \quad \mathrm{X}$ example, saying "ca" for "cat", or "tar" for "star?"

7. Does you child change sounds when he/she speaks? For $\quad$ X $\quad$ X example, saying "too" for "shoe" or "wun" for "run?"

8. Is your child frustrated when he/she speaks?

9. In comparison to other children his/her age, do you think your child has speech problems?

10. Do other people think your child has speech problems?

Note. An " $\mathrm{X}$ " indicates a question that was statistically significant at the .05 level for PCC, PVC, and/or IPC per survey question. Question number 10, represented by "-," was not analyzed because all of the survey responses were " $5 . "$ 


\section{Discussion}

This study used relational and independent analyses to determine speech accuracy and complexity scores for 56 bilingual Spanish-English speaking 4 year-olds in order to develop normative data for this population. The responses to the survey questions answered by the participants' parent were correlated with the speech accuracy and complexity scores in each measure to determine the validity of the survey as a tool for speech disorder identification. Each participant's background information contained three options for a "suspicion of disorder" to be declared by an adult who has heard the child speak. Disorder, based on the single-word articulation test scores, was investigated and the distribution of disordered scores for each measure was calculated. The normative data, survey correlations, and disorder information could be used to improve the effectiveness of identification and assessment of speech disorder for the bilingual Spanish-English pre-school population. The participants' English samples were analyzed because their Spanish samples were not available at the time of this study, however, having English normative data can be beneficial to monolingual English SLPs assessing bilingual Spanish-English children. Additionally, the parent survey correlation results suggest that surveys in different languages may prove valuable tools for diagnosing children who speak other languages that are unfamiliar to the SLP.

\section{Relational and Independent Analysis}

Relational and independent analyses were completed to obtain the means, ranges, standard deviations, and cut-off scores for PCC, PVC, and the IPC. These 
analyses address the first research question of this study regarding typical speech accuracy and complexity scores for bilingual Spanish-English speaking children. This study provides bilingual normative speech development data from the speech accuracy scores on the single-word articulation assessment.

Survey Correlations. Likert values from each question on the parent survey were compared with the PCC, PVC, and mean IPC scores. Statistical significance was found by regression analysis. Six of ten survey questions were significantly correlated with PCC and IPC scores; there was no correlation between survey questions and PVC.

The hypothesis for this study stated that the speech accuracy and complexity scores would be significantly correlated with the survey values. The results support this hypothesis for PCC and IPC, but not for PVC.

Statistically significant PCC and IPC correlations. PCC and IPC correlations showed that the same 6 questions were statistically significant for each measure. This suggests that for parents of bilingual Spanish-English speaking children, they are equally accurate in describing their child's speech in specific areas when considering consonant accuracy as they are when considering combinations of sounds their child does or does not produce. Question number 3, for example, which was about whether or not other people find the child's speech difficult to understand was a statistically significant PCC and IPC correlation for the bilingual SpanishEnglish speakers. This could be explained by the supposition that while parents understand their child's speech very well because they are able to hear them speaking 
in context every day, people who are not as familiar with the child do not. Unfamiliar listeners can often accurately answer a very general question better than a familiar listener about how easy a child is to understand. The parent responses showed that, knowing their child's general comprehensibility with regard to consonant accuracy and speech sound complexity, they were able to judge how well others could understand the child. The survey answers from the parents in the current bilingual study also had statistically significant correlations for PCC and IPC when asked about their child producing specific sounds, leaving out specific sounds, and substituting specific sounds. It's possible that the parents of the bilingual children have an increased awareness of sound accuracy due to the fact that the children are developing two languages and the parents have to pay attention to words produced in both languages in order to meet the child's needs.

The correlations from the parent surveys of bilingual Spanish-English speakers begin to explain some possible speech accuracy scores and parent perceptions unique to this population. The results for correlations from the current study are not in complete agreement with Stertzbach's monolingual Spanish speaker 2005 findings. In that study, there were 13 typically developing 4-year-old participants and the correlation results yielded 6 statistically significant PVC questions and 3 statistically significant PCC questions. In the current study, there was no statistically significant PVC questions and 6 statistically significant PCC questions.

It is interesting that PVC did not have any statistically significant questions for the bilingual speakers in this study. It is possible that for bilingual Spanish- 
English speaking children, consonant errors and accurate consonant blend/consonantvowel combinations are more salient to listeners than vowel errors. In addition, vowel errors are not unusual in bilingual children's' English productions and previous studies have shown that bilingual children make vowel errors during speech development. The longitudinal study by Gilderlseeve-Neumann et al., (2008) showed that vowel errors do increase as bilingual Spanish-English speaking children are developing their language system. Since this is a typical part of development, parents of bilingual children may have a harder time hearing and judging vowel errors when asked to assess their child's speech abilities. Additionally, the parents of Spanish-English bilingual children often speak Spanish and little if any English, which could contribute to their accuracy in judging English vowel productions.

It has been shown that the phonotactic rules of one language often transfer to the second language, including perceptual differences in vowels. A study by Amastae (1982) illustrated the phonotactic rule transfer, vowel differences between monolingual and bilingual speech development, and subsequent decreased vowel accuracy for one bilingual Spanish-English speaking child.

The survey questions (see Table 4-5) are focused on whether a person is able to understand what the child says, the child's ease with producing words, and whether the child leaves out sounds when speaking. None of these specifically address vowels, and vowel errors do not necessarily make a word incomprehensible. Thus, parents of bilingual speakers may not notice vowels as being disordered or incorrect. Maybe the parents had older bilingual children and assumed that the errors present in the 
participant's speech were typical because in the parent's experience with bilingual language development, they were.

It is important to note that complexity measures can be less valuable when PCC is also being compared. The IPC and PCC correlations provided the same information, thus in the current study the inclusion of IPC created a redundancy in results.

\section{Disorder}

The speech accuracy and complexity scores were analyzed to explore the incidence of disorder within each measure. The identification and diagnostic accuracy of three sources, given valid descriptions of "disordered" vs. "typical" when compared to linguistically and culturally matched peers, was examined. The replies to the question "Do you think this child has a speech disorder?" on the parent background survey, examiner questionnaire, and the presence of an existing IFSP were compared to the disordered and typical speech accuracy and complexity scores which were generated in the normative data from the single word articulation assessment.

The normative speech development data provide valid information about disorder in this population. It shows us how many children who have been previously identified as having a speech disorder or are suspected of one, actually have disordered accuracy and/or complexity scores. The identification and diagnosis accuracy levels support that without valid normative data for this population, bilingual children are currently being inaccurately identified and diagnosed. For example, only two of the participants had existing IFSPs, yet (when considering disordered PCC 
scores), there were two others who had scores in the disordered range. It would be interesting to examine how the participants who had existing IFSPs were initially referred, in what language they were assessed, and which specific assessments were done.

Disordered scores. The normative data from the single word articulation assessment was used to calculate the percentage of disordered scores for each measure (PCC, PVC, and IPC). The percentages were as follows: $11 \%$ of the PCC scores were in the disordered range, while both PVC and IPC had 7\% of scores in the disordered range. The $11 \%$ disordered PCC percentage was in agreement with Anderson's 2004 statement that the prevalence of speech disorder is as high as $10 \%-15 \%$.

Identification and diagnosis. The third research question of this study, "Based on the normative data obtained through the single-word assessment used in this study, how accurate are three current methods (parent report, examiner concern, and/or existing IFSP) in identifying and diagnosing bilingual children as having speech disorders?" is addressed below and answered in Tables 5-1 and 5-2. The Tables do not include the PVC disordered scores because they did not have any statistically significant correlations nor do they include IPC because every disordered IPC value also had a disordered PCC score, thus it was a redundant measure for this analysis.

The two methods of identification were the parent who filled out the background survey and the examiner who administered the single-word articulation 
assessment. Each was given the opportunity to reply "yes, "no, or "maybe" to the question "Do you think this child has a speech disorder?"

Accurate identification by parent or examiner. Responses of "yes" or "maybe" and the presence of one or more disordered scores were considered to be an accurate identification. Responses of "no" and typical scores were also considered accurate diagnoses.

Under and over identification by parent or examiner. When the parent or examiner responded "no" but there was one or more disordered scores present, this was considered an under identification. Responses of "yes" or "maybe" by the parent or examiner, but typical scores were considered to be an over identification.

Table 6

Identification

Accurate Identification Under Identification Over Identification

\begin{tabular}{llll}
\hline Parent & 49 & 3 & 4 \\
Examiner & 51 & 2 & 3
\end{tabular}

Note. Parent and examiner identification accuracy when compared to participant PCC scores. See text above for "Accurate," "Under," and "Over" definitions.

Diagnosis. The third method was the presence of an IFSP, which indicated that the child had been identified and assessed by a Speech Language Pathologist who 
determined that there was a speech disorder. The presence or lack of an IFSP was indicated by a "yes" or "no" in each participant's background information.

Accurate diagnosis by existing IFSP. A "yes" in the background information pertaining to IFSP and the presence of one or more disordered scores was considered to be an accurate diagnosis. A response of "no" and typical scores were also considered an accurate diagnosis.

Under and over diagnosis by existing IFSP. When the background information regarding IFSP presence indicated "no" but there were one or more disordered scores present, this was considered an under diagnosis. An indication of "yes" with regard to IFSP presence and typical scores was considered to be an over diagnosis.

Table 7

Diagnosis

Accurate Diagnosis $\quad$ Under Diagnosis Over Diagnosis

Existing IFSP 52 4 0

Note. Diagnosis accuracy as determined by the presence of an existing IFSP when compared to participant PCC scores. See text above for "Accurate," "Under," and "Over" definitions.

As stated by Restrepo and Silverman (2001) and Holm et al., (1999), using bilingual normative data to explore diagnosis accuracy is important because it can help reduce over diagnoses and result in accurate diagnoses of disorder. A portion of a 
study by Holm et al., (1999) used normative data to analyze two children who were previously identified as disordered. Their speech accuracy scores were compared to age and language-matched peers' scores and from that comparison, the researchers were able to determine whether the identification was accurate or not. Similar analyses could be completed with the identification and diagnostic accuracy information from this study.

Limitations. There were some limitations with this study. Although the children were originally assessed in both of their languages (Spanish and English), as has been the "best practice" for bilingual children suggested in numerous studies (Goldstein, 2001b; Salameh, Nettelbladt, \& Norlin, 2003; Yavas \& Goldstein, 1998), only the English samples were analyzed in this thesis. Additionally, the sample size for this study was 56. A larger number of speech samples would have increased the validity of the results. For the PCC, PVC, and IPC results, the speech sample sizes were different for each participant because the number of target words produced was different. While the same word list (picture set) was administered to each participant, every child did not say each word. Additionally, some participants may have the same number of total words but different words within that total, thus containing a different number of consonants and/or vowels. Lastly, the utterances were not transcribed online and some of the samples may have been difficult to appropriately transcribe later because of poor audio recordings due to a quiet child or excessive background noise. 


\section{Conclusion}

This study had three purposes. First, it was designed to develop normative data for a large group of 4 year-old Spanish-English bilingual participants. The data were obtained by analyzing speech accuracy and complexity scores from a singleword articulation assessment administered in English. Second, the speech accuracy and complexity scores were correlated with parent responses from a survey to determine if the parent survey was a valid tool for identifying disorder in the SpanishEnglish bilingual population. Lastly, the topic of disorder for these participants was explored. The scores provided information regarding the effectiveness of three current methods used for speech disorder identification and diagnosis.

The normative speech accuracy and complexity data obtained in this study are unique. There are existing normative data for 4-year-old monolingual English and Spanish speakers but not for bilingual Spanish-English speakers. This data can be used when identifying and diagnosing bilingual children with speech disorder as well as provide valuable information about bilingual speech development. The study by Stertzbach in 2005 obtained speech accuracy (PCC and PVC) data for Spanish speaking 4-year-olds by administering the same single-word articulation assessment as the current study. The ranges and mean scores of the bilingual speakers for each measure (PCC and PVC) were different than for the monolinguals, with the bilingual ranges and means being lower, thus providing evidence that bilingual speech development is different than monolingual speech development and highlighting the need for bilingual normative data. 
The correlations between parent survey responses and speech accuracy and complexity scores provide information about the validity of this identification tool. The results showed that significant correlations were present for six survey questions for both PCC and IPC, while there were no significant correlations for PVC. The correlations provide insight in the area of perception of bilingual speech by analyzing the parent responses about speech and the actual speech scores. Significant correlations with PCC and IPC scores show that parents of bilingual Spanish-English speakers are aware of specific sound (consonant) accuracies and sound blends. This is an interesting contrast with Stertzbach's monolingual Spanish speaker 2005 findings that showed six statistically significant PVC questions and three statistically significant PCC questions. This suggests that for parents of monolingual Spanish speaking children, vowel production is salient enough to be described accurately and with accordance to speech accuracy scores. Consonant production perceptions were not as accurately described according to speech accuracy scores in the monolingual correlations. The inclusion of IPC scores in the correlation results of the current bilingual study resulted in redundancy because every question that had a significant PCC correlation also had a significant IPC correlation. In addition, the fact that there were no significantly correlated questions for PVC within the bilingual participants was quite interesting. It suggests that, for parents of bilingual speakers, vowel accuracy is not clearly perceived as being typical or atypical.

Three of the current methods being used to identify and diagnose speech disorder were explored. The participants' parents were asked whether or not they felt 
that their child had a speech disorder. When the disordered PCC scores (not PVC because of a lack of statistical significance or IPC because of redundancy) were compared to the parents' responses to this question, they were accurate for 49 children, under-identified 3 children and over-identified 4 children. The examiners completed a questionnaire (see Appendix N). They were accurate for 51 children, under-identified 2 children and over-identified 3 children. With regard to existing IFSPs, 52 were accurately diagnosed, 4 were under-diagnosed, and none were over diagnosed.

Further research in speech development is needed. One suggestion would be to calculate the Spanish PCC, PVC, and IPC scores from the same participants as the current study and compare those results with the English scores. In addition, it would be beneficial to calculate the English and Spanish speech scores of the current participants in a longitudinal study to illustrate typical and disordered development. Another suggestion would be to analyze the transcribed single-word samples from the participants in the current study in Spanish and English. This would provide typical and disordered specific sound errors, error patterns, and sound inventories for bilingual speakers in both of their languages and thus, a bilingual child could potentially be assessed in either or both languages; and there would be normative data available to determine an accurate diagnosis. It would also be interesting to compare the normative speech development data from the current study with age-matched monolingual English speakers as well as the IPC (because PCC and PVC were already done by Stertzbach in 2005) of age-matched monolingual Spanish speakers. Finally, 
further survey research should be completed to find correlations for speech accuracy and complexity scores and survey responses for monolingual English speaking children, different ages of Spanish-English bilingual children, bilingual children of the same age but who speak languages that are different than Spanish and English. This information would illustrate whether or not the correlation levels from the current study are typical when compared to correlation levels of other bilingual groups. 


\section{References}

Aldridge, M. (1991). How the language grows up. English Today, 7(1), 14-25.

Amastae, J. (1982). Aspects of bilingual acquisition of English and Spanish. The Journal of the Linguistic Association of the Southwest, 5, 5-19.

Anderson, R. (2004). Phonological acquisition in preschoolers learning a second language via immersion: A longitudinal study. Clinical Linguistics and Phonetics, 18, 183-210.

Armstrong, S. \& Ainley, M. (1992). The South Tyneside Assessment of Phonology (2nd ed.). Northumberland: Stass Publications.

Barlow, J. (2001). Error patterns and transfer in Spanish-English bilingual phonological production. Paper presented at the $26^{\text {th }}$ Annual Boston University Conference on Language Development, Boston, MA.

Davis, B. (2005a). Clinical diagnosis of developmental speech disorders. In A. Kamhi, \& K. Pollock (Eds.), Phonological disorders in children (pp. 3-21). Baltimore: Paul H. Brookes Publishing.

Dodd, B., Holm, A., \& Wei L. (1997). Speech disorder in preschool children exposed to Cantonese and English. Clinical Linguistics and Phonetics, 11, 229-243.

Fenson, L., Dale, P., Reznick, S., Thal, D., Bates, E., Hartung, J., Pethick, S., \& Reilly, J. (1993). MacArthur Communicative Development Inventories; User's guide and technical manual. San Diego, Singular Publishing Group, Inc.

Gardner, M. (1990). Expressive one-word picture vocabulary test. Austin, TX: ProEd. 
Gildersleeve-Neumann, C., Kester, E., Davis, B., \& Peña, E. (2008). English speech sound development in preschool-aged children from bilingual English-Spanish Environments. Language, Speech, and Hearing Services in Schools, 1-40.

Gildersleeve-Neumann, C., Peña, E., Davis, B., Kester, E. (2009). Effects on L1 during early acquisition of L2: Speech changes in Spanish at first English contact. Bilingualism: Language and Cognition, 12, 259-272.

Gillon, G. (2005). Facilitating Phoneme Awareness Development in 3- and 4- YearOld Children with Speech Impairment. Language, Speech, and Hearing Services in Schools, 36(4), 308-324.

Goldman, R., \& Fristoe, M. (2000). Goldman-Fristoe Test of Articulation, Second Edition (GFTA-2). Minneapolis, MN: Pearson Assessments.

Goldstein, B. (2001a). Transcription of Spanish and Spanish-influenced English. Communication Disorders Quarterly, 23, 54-60.

Goldstein, B. (2001b). Assessing phonological skills in Hispanic/Latino children. Seminars in Speech and Language, 22, 39-49.

Goldstein, B., Fabiano, L., \& Washington, P. (2005). Phonological skills in predominantly English-speaking, predominantly Spanish-speaking, and Spanish-English bilingual children. Language, Speech, and Hearing Services in Schools, 36, 210-218.

Goldstein, B., \& Washington, P. (2001). An initial investigation of phonological patterns in typically developing 4-year-old Spanish-English bilingual children. Language, Speech, and Hearing Services in Schools, 32,153-64. 
Gutierrez-Clellen, V., \& Kreiter, J. (2003). Understanding child bilingual acquisition using parent and teacher reports. Applied Psycholinguistics, 24, 267-288.

Holm, A., \& Dodd, B. (1999). An intervention case study of a bilingual child with phonological disorder. Child Language Teaching and Therapy, 15, 139-158.

Holm, A., Dodd, B., Stow, C., \& Pert, S. (1999). Identification and differential diagnosis of phonological disorder in bilingual children. Language Testing, 16(3), 271-292.

Howell, P., \& Au-Yeung, J. (2007). Phonetic complexity and stuttering in Spanish. Clinical Linguistics and Phonetics, 21:2, 111-127.

Howell, P., Au-Yeung, J., Yaruss, S., \& Eldridge, K. (2006). Phonetic difficulty and stuttering in English. Clinical Linguistics and Phonetics, 20:9, 703-716.

Ingram, D. (2002). The measurement of whole-word productions. Journal of Child Language,29, 713-733.

Jakielski, K.J. (1998). Motor organization in the acquisition of consonant clusters. Unpublished doctoral dissertation, University of Texas at Austin. Ann Arbor, MI: UMI Dissertation services.

Oller, D. K. \& Delgado, R. (2000). Logical International Phonetics Program (Version 2.02). [Software Program]. Miami, Florida: Intelligent Hearing Systems.

Pendergast, K., Dickey, S., Selmar, J., \& Soder, A. (1997). Photo articulation test - 3. Austin, TX: Pro-Ed.. 
Restrepo, M. A. (1998). Identifiers of predominantly Spanish-speaking children with languageimpairment. Journal of Speech, Language, and Hearing Research, 41, 1398- 1411.

Restrepo, M., \& Silverman, S. (2001). Validity of the Spanish Preschool Language Scale-3 for use with bilingual children. American Journal of Speech-Language Pathology, 10, 382-393.

Salameh, E., Nettelbladt, U., \& Norlin, K. (2003). Assessing phonologies in bilingual Swedish-Arabic children with and without language impairment. Child Language Teaching and Therapy, 338-364.

Schnitzer, M., \& Krasinski, E. (1996). The development of segmental phonological production in a bilingual child: A contrasting second case. Journal of Child Language, 23, 547-571.

Secord, W., \& Donohue, J. (2002). Clinical Assessment of Articulation and Phonology. Greenville, SC: Super Duper Publications.

Schraeder, T., Quinn, M., Stockman, I., \& Miller, J. (1999). Authentic assessment as an approach to preschool speech-language screening. American Journal of Speech-Language Pathology,6, 195-200.

Shriberg, L., Austin, D., Lewis, B., McSweeney, J. \& Wilson, D. (1997). The percentage of consonants correct (PCC) metric: Extensions and reliability data. Journal of Speech, Language, and Hearing Research, 40, 708-722. 
Stertzbach, J. (2005). Parent report as a screening tool of speech disorders in Spanishspeaking preschool children. A Master's Special Project, Portland State University Speech and Hearing Sciences Graduate Program.

Stoel-Gammon, C. (1998). Role of babbling and phonology in early linguistic development. In A. Wetherby, S. Warren, \& J. Reichle (Eds.), Transitions in prelinguistic communication (pp. 87-110). Baltimore: Paul H. Brookes Publishing.

Thal, D., O'Hanlon, L., Clemmons, M., \& LaShon, F. (1999). Validity of a parent report measure of vocabulary and syntax for preschool children with languageimpairment. Journal of Speech, Language, and Hearing Research, 42, $482-496$.

Thorndike, R., Hagen, E., \& Sattler. (1986). The Stanford-Binet intelligence scale $\left(4^{\text {th }}\right.$ ed.). Chicago: The Riverside Publishing Company.

U.S. Census Bureau, American Community Survey. (2008) American community survey 1-year estimates (S1601. Language Spoken at Home.) Retrieved from http://www.census.gov/acs/www/index.html

Vihman, M. (2002). Getting started without a system: From phonetics to phonology in bilingual development. The International Journal of Bilingualism, 6, 239-254.

Yavas, M., \& Goldstein, B. (1998). Phonological assessment and treatment of bilingual speakers. American Journal of Speech-Language Pathology, 7, 4958. 
Zimmerman, I., Steiner, V., \& Pond, R. (2002). Preschool Language Scale-Fourth Edition. San Antonio, TX: The Psychological Corporation. 


\section{Appendix A: Flyer- English}

\section{Portland State UNIVERSITY}

November 2007

Dear Parents,

Thank you so much for agreeing to allow your child to participate in my study on English and Spanish speech development. I think it is a fun experience for your child, and it helps us understand speech better. We have begun asking your children to name pictures, and hope to be do same pictures again in May.

Attached is a survey about your child's development. This is the same survey mentioned in the form you signed. Please fill this out and return this in the attached envelope to your child's teacher We will call you in the my students am happy to complete this survey with you over the phone. We will call you in the next week or so to see if you have any questions or concerns about the
survey.

Included with the survey is a $\$ 5$ gift certificate as a thank you for completing the survey. In addition, your child will receive a book from me as a thank you after I have collected the speech samples from all students, probably right before or after the winter holidays. Your child will receive an additional book in May when we finish the study for the year.

Thank you for your support and participation. Please call me at 503.725 .3230 or email me at cegn@pdx.edu if you have questions.

Sincerely,

$$
\text { Christinaj }
$$

Christina Gildersleeve-Neumann, Ph.D., CCC-SLP

Portland State University 


\section{Appendix B: Flyer- Spanish}

\section{PoRTLAND StATE UNIVERSITY}

Noviembre de 2007

Queridos Padres,

Gracias por permitir que su hijo o hija participe en mi proyecto del desarrollo del habla en niños que aprenden inglés o español. Pienso que es una experiencia interesante para su hijo, y la información nos ayuda mucho a entender el habla de niños. Hemos vacaciones en diciembre. Pedimos que sus hijos nombren los dibujos otra vez en mayo.

He incluido un cuestionario sobre el desarrollo de su niño. Es el mismo cuestionario que mencioné en el formulario que Ud. firmó. Por favor, llene este cuestionario y podemos ayudará a llenar el cuestionario por telestro de su hijo. Si Ud. prefiere, le ver si tiene preguntas.

Como agradecimiento por su ayuda en este proyecto, he incluido un certificado de cinco dolares. Además, todos los niños recibirán un libro una vez que hayamos recolectado la información en diciembre y otro vez en mayo.

Muchísimas gracias por su ayuda y participación! Si tiene preguntas, por favor llaméme al 503.725.3230 o mandéme un email a cegn@pdx.edu.

Muy atentamente,

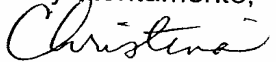

Christina Gildersleeve-Neumann, Ph.D., CCC-SLP

Portland State University 


\title{
Appendix C: Consent Form
}

\author{
Parents \\ BE PART OF AN \\ IMPORTANT \\ PROJECT \\ Speech Development in Spanish-English \\ Bilingual Preschoolers
}

Christina Gildersleeve-Neumann is conducting a study to learn more about how bilingual children learn to speak two languages. You and your child were selected as possible participants in this study because your child is of preschool age and has been exposed to Spanish and/or English in their home, and are participating in Head Start at the Knott site, where this study will be conducted.

\section{If I Agree to Participate. What Will I Have To Do?}

If you decide to take part in this project,

- You will be asked to fill out a two-part language and developmental history questionnaire about your child. You can fill this out yourself, or I can ask the questions and fill it out for you. This should take about 10 minutes.

- Every 4 months, your child will meet with me and another teacher for 15 minutes in English, and 15 minutes in Spanish as appropriate. (Please note that each time your child will be asked if they want to participate, and they will only participate if they verbally agree to do participate). These meetings will happen until your child turns 6 . These meetings could be at the school, at a time when he/she is normally in class, or they could be scheduled separately. During the meeting, your child will be encouraged to speak in English or in Spanish while looking at various pictures and books. If your child is bilingual, one session will be conducted in English and another in Spanish. The sessions will be audio- and video- recorded so that the researcher can write down words your child said at a later time.

- At the beginning of next year, and the year after, I will contact you through a phone call to ask a few questions about your child's language and development. This will be about 5 minutes, just to see if there are any changes in language use or development, and to check to see if you have any questions. 
- You don't have to agree to do this if you don't want to. And if your child doesn't want to, they won't be pushed to participate.

Although your child may miss some class time for this project, the researcher will work with the classroom teacher to find appropriate and convenient times within the classroom schedule for children to participate in the research.

\section{What Will I Get In Return?}

- You will receive a $\$ 5$ gift certificate for completing the questionnaire every year.

- The greatest benefit of this study is indirect as it may help to increase knowledge on bilinguals, which may help teachers and other professionals understand how children learn two languages. Right now, we know a lot about how children learn English, some about how children learn Spanish, but very little about how children learn both at the same time. We want to understand this better so teachers know when it's normal for bilingual children to speak unclearly because they're still learning, and when a child is very unclear and would benefit from speech therapy.

Your child will receive a small gift each time they participate, a book or a gift certificate.

- More complete knowledge about language development in Spanish/English bilingual children will also help schools better serve your children.

\section{What Are You Doing To Protect Our Privacy?}

Your privacy is very important to us. We have done many things to protect you:

- Any information that is obtained in connection with this study and that can be linked to you or identify will be kept confidential. This means that the names of people who take part in the study will not be given to anyone else. No one other than the researcher will have access to the information.

- All videotapes, audiotapes, and written records will be stored in a locked file cabinet at Portland State

University. Information collected from participants will be used for research purposes only.

\section{What if I have questions?}

If you have concerns or problems about your participation in this study or your rights as a research subject, please contact the Human Subjects Research Review Committee, Office of Research and Sponsored

Projects, 111 Cramer Hall, Portland State University, (503) 725-4288. If 
you have questions

about the study itself, contact Christina Gildersleeve-Neumann by email at cegn@pdx.edu, or by mail at the Speech and Hearing Sciences Department, Portland State University, PO Box 751, Portland, OR 97207 or by phone, (503) 725-3230.

\section{Why do I sign this form?}

This is a consent form. Your signature below means that:

- You have read it or it has been read to you, and understand what it says.

- You and your child are willing to take part in the study by the researcher.

- You know that you do not have to take part in this study. And even if you agree, you can change your mind and stop at any time.

- You will get a copy of this form to keep for yourself.

Signature

Date

Witness

Date 


\section{Appendix D: Parent Survey (background- English)}

Today's Date:

\section{BACKGROUND SURVEY \\ Study of Language Development in English-Only and Bilingual Children}

Please fill this out and return it to me, Christina Gildersleeve-Neumann, through your child's teacher. If you prefer, you can complete these questions with me over the phone. I or one of my students will call in a few days to see if you have questions. Thank you for your help!

Child's Name:

Child's Teacher's Name:

Your Name: Your Relationship to the Child:

Child's Age:

Section 1. DEVELOPMENT HISTORY. These questions help us understand your child's development. If you have questions or concerns about a question, please feel free to not answer or to ask for clarification.

1. What is your child's birthdate?

2. Where was your child born?

3. Where were the child's parents born?

4. What language(s) do the child's parents speak?

5. Is this your child's first or second year in Head Start?

6. How old was your child when he or she first babbled (eg., say bababa or dadada)?

7. How old was your child when he or she first spoke three different words? What were they?

8. How old was your child when he or she started saying 2 and 3 word sentences on a regular basis?

9. How old was your child when she or he first spoke in sentences, even though some of the words in the sentence may have been missing?

10. Has your child ever had his or her hearing checked? What were the results?

11. Has your child been treated for ear infections? If yes, how many times? When were they?

12. Has your child ever had a serious illness or been hospitalized? If yes, please explain.

13. Does your child have any diagnosed medical conditions? If so, please explain.

14. Who are the members of your child's family? Please note ages of sisters and brothers.

15. Who are the main people with whom your child interacts?

16. Do you have any concerns about your child's general development? If so, what are they? 


\title{
Appendix E: Parent Survey (background- Spanish)
}

\author{
CUESTIONARIO SOBRE EL DESARROLLO DE SU NIÑO \\ Estudio sobre el desarrollo del lenguaje en niños \\ que hablan sólo inglés o son bilingües
}

Fecha:

Por favor, llene este cuestionario y devuélvalo al maestro de su hijo/a en el sobre que adjuntamos. Si prefiere, podemos llenar este cuestionario por teléfono. Le llamaremos en pocos días para ver si tiene dudas o preguntas. Muchas gracias por su colaboración.

Nombre de su Hijo/a:

Su Nombre:
Nombre de su Maestro/a

Relación con el niño:
Edad del Niño:

Sección 1. EL DESARROLLO DE SU HIJO. Estas preguntas nos ayudarán a comprender mejor el desarrollo de su niño. Si tiene dudas sobre cualquier pregunta, no la conteste o pregúntennos y con mucho gusto le ayudaremos.

1. ¿Cuándo nació su hijo/hija?

2. ¿Dónde nació su hijo/a?

3. ¿Dónde nacieron los padres del niño?

4. ¿Qué idioma(s) hablan los padres del niño?

5. ¿Es este el primero or segundo año de su hijo/a en el Head Start?

6. ¿Qué edad tenía su bebé cuando comenzó a balbucear? (por ejemplo, "ba ba ba", "pa pa ba")

7. ¿Qué edad tenía su hijo/hija cuando dijo las tres primeras palabras que usted pudo distinguir? ¿Cuáles fueron estas palabras?

8. ¿Qué edad tenía su hijo/hija cuando comenzó a decir oraciones de 2 ó 3 palabras de forma regular?

9. ¿Qué edad tenía su hijo/hija cuando comenzó a hablar en oraciones completas, aunque le haya faltado una que otra palabra?

10. ¿Le han hecho a su hijo/hija un examen del oído? ¿Cuáles fueron los resultados?

11. ¿Ha recibido su hijo/hija tratamiento por infecciones del oído? ¿Cuántas veces? ¿Cuándo?

12. ¿Ha sufrido su hijo/hija de enfermedades serias o ha sido alguna vez hospitalizado(a)? Por favor, explique.

13. ¿Tiene su hijo/hija alguna condición médica o enfermedad que le haya sido diagnosticada? Por favor, explíque.

14. Haga una lista de los miembros de su familia (papá, mamá, hermanos, etc) y la edad de los hermanos.

15. ¿Cuáles son las personas con las que su hijo/hija pasa la mayor parte del tiempo?

16. ¿Tiene alguna preocupación sobre el desarrollo en general de su hijo/hija? ¿Cuáles son sus dudas? 


\section{Appendix F: Parent Survey (language- English)}

SECTION 2. LANGUAGE SURVEY. The questions below help us understand your child's language development, particularly how often and with whom your child speaks English and other languages. If your child does not speak Spanish, only answer question 1 of this section and move on to Section 3. If you have questions or concerns about a particular question, please feel free to not answer, or to ask me for clarification.

1. Does your child speak and hear only English? If no, please complete the questions below. If yes, skip to Section 3 of this survey.

2. For how many years has your child been exposed to Spanish (or other language)?

3. Which dialect of Spanish (or other language(s)) does your child speak?

4. What language(s) does your child hear at home? If more than one, give approximate hours/day.

5. When and what was your child's first exposure to English?

6. Does your child use any English words at home? If so, how often?

7. What other exposure does your child have to English? Please list about how many hours in a day for each:

Television
Other (Please describe) __ Radio

8. Approximately how many hours per week outside of school is your child exposed to English?

9. Approximately how many hours per week outside of school is your child exposed to Spanish?

10. Whom does your child spend time with in a typical week? Please check the appropriate boxes below to indicate amount of time spent together.

\begin{tabular}{|c|c|c|c|c|c|}
\hline & 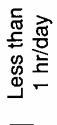 & 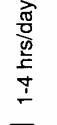 & 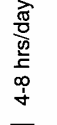 & 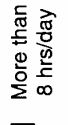 & $\begin{array}{l}\text { What languages do they speak when } \\
\text { they are around your child? }\end{array}$ \\
\hline Mother & $\square$ & $\square$ & $\square$ & $\square$ & \\
\hline Father & $\square$ & $\square$ & $\square$ & $\square$ & \\
\hline Babysitter & $\square$ & $\square$ & $\square$ & $\square$ & \\
\hline Siblings & $\square$ & $\square$ & $\square$ & $\square$ & \\
\hline $\begin{array}{l}\text { Other } \\
\text { relatives }\end{array}$ & $\square$ & $\square$ & $\square$ & $\square$ & \\
\hline Teacher & $\square$ & $\square$ & $\square$ & $\square$ & \\
\hline Friends & $\square$ & $\square$ & $\square$ & $\square$ & \\
\hline Other & $\square$ & $\square$ & $\square$ & $\square$ & \\
\hline Other & $\square$ & $\square$ & $\square$ & $\square$ & \\
\hline
\end{tabular}




\section{Appendix G: Parent Survey (language- Spanish)}

SECCION 2. CUESTIONARIO SOBRE LENGUAJE. Las siguientes preguntas nos ayudarán a comprender mejor como su hijo/a está aprendiendo a hablar, especialmente con qué frecuencia y con quién su niño/a habla español o inglés. Si no está seguro/a sobre cualquiera de estas preguntas, no la conteste, o pregúntennos y con mucho gusto le ayudaremos. Muchas gracias por su colaboración.

1. ¿Por cuántos años ha estado su hijo/hija expuesto al español (o cualquier otro idioma)?

2. ¿Qué dialecto de español (o cualquier otro idioma) habla su hijo/hija?

3. ¿Qué idioma escucha su hijo/hija hablar en casa? Si es más de un idioma, por favor, indique horas al día que escucha cada idioma.

4. ¿Cuándo comenzó su hijo/hija a escuchar inglés por primera vez?

5. ¿Utiliza su hijo/hija palabras en inglés cuando habla en casa? ¿Con qué frecuencia?

6. ¿De qué otra forma está su hijo/hija está expuesto al inglés? Indique las horas al día: — Televisión Radio

_ Otro (Por favor, describa)

_ Otro (Por favor, describa)

7. ¿Afuera de la escuela, apróximadamente cuantas horas en la semana esta expuesto al inglés su hijo?

8. ¿Afuera de la escuela, apróximadamente cuantas horas en la semana esta expuesto al español su hijo?

9. ¿Con quiénes pasa su hijo/hija la mayor parte del tiempo? Indique a continuación en los espacios apropiados la cantidad de tiempo que su niño(a) pasa con diferentes personas.

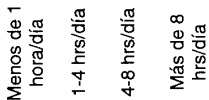

Madre

Padre

Niñera

Hermanos

Otros

parientes

Maestros

Amigos

Otro

Otro
¿Qué idioma hablan cuando están con su hijo o hija? 


\section{Appendix H: Parent Survey (speech- English)}

Section 3. SPEECH DEVELOPMENT QUESTIONS. These questions help us understand how clearly your child speaks, as well as whether you have concerns about your child's speech development. Please circle one for each question.

1. Is your child's pronunciation difficult to understand? (Circle one)
Never
Rarely
Sometimes
Frequently
All the time.

2. In comparison to other children his/her age, do you think your child is difficult to understand? (Circle one)
Never
Rarely
Sometimes
Frequently
All the time.

3. Do other people think your child is difficult to understand? (Circle one)
Never
Rarely
Sometimes Frequently
All the time.

4. Does your child have difficulty pronouncing words? (Circle one)

Never Rarely Sometimes Frequently All the time.

5. Does your child have problems producing certain sounds? (Circle one)

Never Rarely Sometimes Frequently All the time.

6. Does your child leave out sounds when he/she speaks? For example, saying "ca" for "caf", or "tar" for "star?" (Circle one)
Never
Rarely
Sometimes Frequently
All the time.

7. Does your child change sounds when he/she speaks? For example, saying "'too" for "shoe" or "wurn" for "run?" (Circle one)

Never Rarely Sometimes Frequently All the time.

8. Is your child frustrated when he/she speaks? (Circle one)

Never Rarely Sometimes Frequently All the time.

9. In comparison to other children his/her age, do you think your child has speech problems? (Circle one)
No
Probably not
Maybe
Probably
Yes

10. Do other people think your child has speech problems? (Circle one)

No Probably not $\quad$ Maybe Probably

YOU'RE DONE! THANK YOU SO MUCH FOR YOUR HELP! 


\section{Appendix I: Parent Survey (speech- Spanish)}

Sección 3. PREGUNTAS SOBRE COMO HABLA SU HIJO. Las siguientes preguntas nos ayudarán a comprender que tan claramentesu puede hablar su hij(a) y lo que usted piensa de como su niño(a) está hablando. Por favor, marque una respuesta por pregunta.

1. ¿Le es difícil comprender la pronunciación de su hijo/a? (marque uno)

$$
\text { Nunca Rara vez A veces Con frecuencia Todo el tiempo. }
$$

2. Si compara a su hijo/a con otros niños de la misma edad, ¿cree que es difícil de entender? (marque uno)

Nunca Rara vez A veces Con frecuencia Todo el tiempo.

3. ¿Hay otros parientes o amigos que piensan que su hijo/a es difícil de entender? (marque uno)

Nunca Rara vez A veces Con frecuencia Todo el tiempo.

4. ¿Cree que su hijo/a tiene dificultad pronunciando palabras? (marque uno)

Nunca Rara vez A veces Con frecuencia Todo el tiempo.

5. ¿Tiene su hijo/a problemas diciendo ciertos sonidos de palabras? (marque uno)

Nunca Rara vez A veces Con frecuencia Todo el tiempo.

6. Cuando su hijo/a habla, ¿corta sonidos en las palabras? Por ejemplo, dice "so-" en vez de "sol" o "ota" en vez de "bota"? (marque uno)

Nunca Rara vez A veces Con frecuencia Todo el tiempo.

7. Cuando su hijo/a habla, ¿cambia sonidos en las palabras? Por ejemplo, dice "tucio" en vez de "sucio"? (marque uno)
Nunca Rara vez
A veces Con frecuencia
Todo el tiempo.

8. Cuando su hijo/a habla, ¿se le nota frustrado?

Nunca Rara vez A veces Con frecuencia Todo el tiempo.

9. Si compara a su hijo/a con otros niños de la misma edad, ¿cree usted que tiene problemas al hablar? (marque uno)
No
Probablemente no
Tal vez
Es posible
Sí

10. ¿Hay otros parientes o amigos que piensan que su hijo/hija tiene problemas con su idioma? (marque uno)
No
Probablemente no
Tal vez
Es posible
Sí

\section{¡ES TODO! ¡MUCHAS GRACIAS POR SU COLABORACION!}




\section{Appendix J: Bilingual Level- English}

\section{On questions 11-18, please circle the appropriate number for each question.}

11. How well does your child understand English? 12. How well does your child understand Spanish?

1 - A few words.

2 - A little of what is said.

3 - Generally what is said.

4 - A lot of what is said.

5 - Almost all or all of what is said.
1 - A few words.

2 - A little of what is said.

3 - Generally what is said.

4 - A lot of what is said.

5 - Almost all or all of what is said.

13. How well does your child speak English?

1 - Child cannot speak the language but knows a few words.

2 - Child cannot speak the language well but knows some words and phrases.

3 - Child speaks the language a little but with many grammatical errors and a limited vocabulary.

4 - Child speaks the language well but with some grammatical errors and a moderate vocabulary.

5 - Child speaks the language like a native English speaker with very few errors and a good vocabulary.

14. How well does your child speak Spanish?

1 - Child cannot speak the language but knows a few words.

2 - Child cannot speak the language well but knows some words and phrases.

3 - Child speaks the language a little but with many grammatical errors and a limited vocabulary.

4 - Child speaks the language well but with some grammatical errors and a moderate vocabulary.

5 - Child speaks the language like a native Spanish speaker with very few errors and a good vocabulary.

15. How often does your child speak English?

1 - Never

2- A little

3-Sometimes

4- Most of the time

5 - All of the time

17. How often does your child hear English?

1 - Never

$2-$ A little

3- Sometimes

4 - Most of the time

5 - All of the time
16. How often does your child speak Spanish?

1 - Never

2- A little

3 - Sometimes

4-Most of the time

5 - All of the time

18. How often does your child hear Spanish?

1 - Never

2-A little

3 - Sometimes

4 - Most of the time

5 - All of the time 


\section{Appendix K: Bilingual Level-Spanish}

\section{Por preguntas 10 a 17, por favor marque el número apropriado para cada pregunta.}

10. ¿Qué tan bien comprende su hijo/a el español?

1 Pocas palabras.

2 Algo de lo que le dicen.

3 En general comprende lo que le dicen.

4 Mucho de lo que le dicen.

5 Casi todo de lo que le dicen.
11. ¿Qué tan bien comprende su hijo/a el inglés?

1 Pocas palabras.

2 Algo de lo que le dicen.

3 En general comprende lo que le dicen.

4 Mucho de lo que le dicen.

5 Casi todo de lo que le dicen.

12. ¿Qué tan bien habla su hijo/hija el español?

1 - No puede hablarlo, pero sabe palabras.

2 - No puede hablarlo, pero sabe algunas palabras y frases.

3 - Puede hablarlo un poco, pero con errores y poco vocabulario.

4 - Puede hablar bien, pero todavía con errores de gramática y con buen vocabulario

5 - Puede hablar tan bien como cualquier nativo del idioma con pocos errores y buen vocabulario.

13. ¿Qué tan bien habla su hijo/hija el inglés?

1 - No puede hablarlo, pero sabe palabras.

2 - No puede hablarlo, pero sabe palabras y frases.

3 - Puede hablarlo un poco, pero con errores y poco vocabulario.

4 - Puede hablarlo bien, pero todavía con errores y con buen vocabulario.

5 - Puede hablarlo tan bien como cualquier nativo con pocos errores y muy buen vocabulario.

14. ¿Con qué frecuencia su hijo/a habla español?

1 - Nunca

2 - Un poco

3- La mitad del tiempo

4 - La mayoría del tiempo

5 - Todo el tiempo

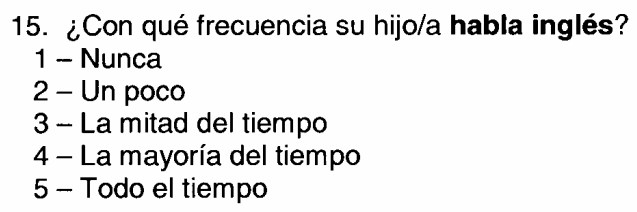

16. ¿Con qué frecuencia su hijo/a escucha español?

1 - Nunca

2 - Un poco

3- La mitad del tiemlpo

4 - La mayoría del tiempo

5 - Todo el tiempo

17. ¿Con qué frecuencia su hijo/a escucha inglés?

1 -Nunca

2- Un poco

3-La mitad del tiempo

4 - La mayoría del tiempo

5 - Todo el tiempo 


\section{Appendix L: Bilingual Scale}

Name of Participant

ID\#

BILINGUAL LEVEL SCALE

\begin{tabular}{|c|c|c|c|}
\hline Category & Abbrev. & $\begin{array}{c}\text { Scale } \\
\text { Number }\end{array}$ & Hours of Exposure to English \\
\hline Functional English & FE & 5 & $\begin{array}{l}>13 \mathrm{hrs} / \text { day of English or } \\
>91 \mathrm{hrs} / \text { week of English }\end{array}$ \\
\hline $\begin{array}{l}\text { Predominantly } \\
\text { English }\end{array}$ & Es & 4 & $\begin{array}{l}12 \mathrm{l} / 2 \text { to } 13 \mathrm{hrs} / \text { day of English or } \\
87 \mathrm{l} / 2 \text { to } 91 \mathrm{hrs} / \text { week of English }\end{array}$ \\
\hline $\begin{array}{l}\text { Bilingual } \\
\text { English/Spanish }\end{array}$ & B & 3 & $\begin{array}{l}1 \mathrm{1} / 2 \text { to } 12 \mathrm{1} / 2 \mathrm{hrs} / \text { day of English or } \\
10 \mathrm{1} / 2 \text { to } 87 \mathrm{1} / 2 \mathrm{hrs} / \text { week of English }\end{array}$ \\
\hline $\begin{array}{l}\text { Predominantly } \\
\text { Spanish }\end{array}$ & $\mathrm{Se}$ & 2 & $\begin{array}{l}1 \text { to } 1 \mathrm{l} / 2 \mathrm{hrs} / \text { day of English or } \\
7 \text { to } 10 \mathrm{1} / 2 \mathrm{hrs} / \text { week of English }\end{array}$ \\
\hline Functional Spanish & FS & 1 & $\begin{array}{l}<1 \mathrm{hr} / \text { day of English or } \\
<7 \mathrm{hrs} / \text { week of English }\end{array}$ \\
\hline
\end{tabular}

BILINGUAL LEVEL

Spanish hours per week

English hours per week
English Exposure Date:

L1:

\section{CONSIDERATIONS:}

-The child is awake 13 hours per day or 91 hours per week.

1. Head Start Class:

- English speaking class $=12$ hours/week of English (automatic BL3)

- Spanish speaking class $=$ No English (Vania/Maria)

2. English exposure at home:

Parents

Siblings

hours $\mathrm{x}$ hours $\mathrm{x}$

Relatives

hours $\mathrm{x}$
hours $\mathrm{x}$
hours $\mathrm{x}$

-

days $=$ days $=$ days $=$ hrs/week

3. Other English exposure:
Childcare
hours $\mathrm{x}$
Friends hours $\mathrm{x}$ hours $\mathrm{x}$ days $=$ days $=$ week
Other days $=$ hrs/week
TOTAL HOURS OF ENLGISH EXPOSURE hrs/week

\section{Comments:}




\section{Appendix M: Word List}

Bilingual Speech Development - English Stimuli

Child's Name:

Child's Teacher:

$S / Y / T^{*}$

_apple

_ apples

baby

_ball

_balls

_five

_six

_banana

bath

_bathtub

_bird

- black

— books

- boy

_brush

_butterfly

candle

_ carrots

_cars

_ caterpillaı

_chair

chicken

chocolate

church

clouds

cookies

_ crayon

_dinosaur

_dog

_drinking

drum

_eggs

elephant

feather

finger

- fire

firetruck

_ fishing

Date:

Examiner:

S/YIT

_fish

five

flower

_foot

fork

_french fries

_ frog

_ giraffe

_ girl

glasses

_ grapes

_ guitar

hamburger

hammer

hand

helicopter

horse

house

ice cream

_jacket

_ juice

_ jumping

_kitchen

_lamp

_ leaf

_lips

_mouth

- teeth

_tongue

_little

_big

_milk

_mirror

_ mountains

_mouse

- mouth

_ nest

_orange

\section{S/Y/T}

_ pancakes

_pants

pencil

_pig

_planes

_ puppy

_rainbow

_red

__ring

_school

_ scissors

- seven

sheep

_shower

slide

smile

_smoke

snake

spider

_squirre

_stars

_ strawberry

_ string

_swinging

teacher

teeth

three

_throwing

_tiger

_toothpaste

_tongue

_toys

truck

vacuum

- vacuum

- watch

- yellow

- yellow

_zipper

*S-spontaneous, $Y$ - delayed imitation, $T$ - direct imitation 


\title{
Appendix N: Examiner Questionnaire
}

\author{
Bilingual Speech Development - English Stimuli December 2004 \\ Child's Name: \\ Intelligibility (\%? Any Comments?)
}

Please comment on the following.

Setting Comments (i.e., noise level, interruptions)

Child Behavior/Emotional Comments (shy, mad, other)

Factors Impacting Intelligibility (Loudness, Other)

Vocabulary \& Language Comments (Comment on syntax, morphology, semantic relationships, pragmatics)

Did child attempt any Spanish words for English vocabulary?

Does child appear to you to have a speech delay or disorder?

Does the child appear to be atypical in any way? (Language, physical, IQ, etc.) Please comment.

Other Comments? 


\section{Appendix O: Index of Phonetic Complexity}

The Index of Phonetic Complexity \& Explanation of Categories

\begin{tabular}{|c|c|c|c|}
\hline \multicolumn{4}{|c|}{$\begin{array}{c}\text { Index of Phonetic Complexity } \\
\text { (Jakielski, 2006) }\end{array}$} \\
\hline category & points assigned for: & no points for: & one point for each: \\
\hline 1 & $\begin{array}{c}\text { consonants } \\
\text { by } \\
\text { place class }\end{array}$ & $\begin{array}{l}\text { labials } \\
\text { coronals } \\
\text { glottals }\end{array}$ & Dorsal \\
\hline 2 & $\begin{array}{l}\text { consonants } \\
\text { by } \\
\text { manner class }\end{array}$ & $\begin{array}{l}\text { stops } \\
\text { nasals } \\
\text { glides }\end{array}$ & $\begin{array}{l}\text { Fricative } \\
\text { affricate } \\
\text { liquid }\end{array}$ \\
\hline 3 & $\begin{array}{l}\text { vowels } \\
\text { by class }\end{array}$ & $\begin{array}{l}\text { monophthongs } \\
\text { diphthongs }\end{array}$ & Rhotic \\
\hline 4 & $\begin{array}{c}\text { word } \\
\text { shape }\end{array}$ & $\begin{array}{c}\text { words that end } \\
\text { with a vowel }\end{array}$ & $\begin{array}{l}\text { time a consecutive single } \\
\text { consonant varies by place }\end{array}$ \\
\hline 5 & $\begin{array}{l}\text { word length } \\
\text { in syllables }\end{array}$ & $\begin{array}{l}\text { monosyllabic or disyllabic } \\
\text { words }\end{array}$ & $\begin{array}{l}\text { three- }(+/=) \\
\text { syllable word }\end{array}$ \\
\hline 6 & $\begin{array}{l}\text { singleton consonants } \\
\text { by place variegation }\end{array}$ & $\begin{array}{l}\text { words with place } \\
\text { reduplicated singletons }\end{array}$ & $\begin{array}{l}\text { word with place } \\
\text { variegated singletons }\end{array}$ \\
\hline 7 & contiguous consonants & no clusters & consonant cluster \\
\hline 8 & cluster by type & homorganic clusters & heterorganic cluster \\
\hline
\end{tabular}

\section{Examples of complexity ratings for words}

\begin{tabular}{|c|c|c|c|}
\hline mommy & mami & $=$ & 0 points \\
\hline pizza & pits' & $=$ & 2 points \\
\hline coat & kot & & $=3$ points \\
\hline hors & hçrs & $=$ & 5 points \\
\hline school & skul & $=$ & 6 points \\
\hline
\end{tabular}




\section{Appendix P: Pearson Coefficients For All Survey Questions}

\begin{tabular}{|c|c|c|c|c|c|c|c|c|c|}
\hline & \multicolumn{3}{|c|}{ PCC } & \multicolumn{3}{|c|}{ PVC } & \multicolumn{3}{|c|}{ IPC } \\
\hline Questions & $\begin{array}{l}\text { signifi- } \\
\text { cance }\end{array}$ & $r$ & $\mathrm{r} 2$ & $\begin{array}{l}\text { signifi- } \\
\text { cance }\end{array}$ & $r$ & $\mathrm{r} 2$ & $\begin{array}{l}\text { signifi- } \\
\text { cance }\end{array}$ & $\mathrm{r}$ & $\mathrm{r} 2$ \\
\hline $\begin{array}{l}\text { 1. Is your child's } \\
\text { pronunciation } \\
\text { difficult to } \\
\text { understand? }\end{array}$ & 0.000 & \begin{tabular}{|c|}
+.444 \\
(positive \\
moderate)
\end{tabular} & $19.7 \%$ & 0.719 & 0.048 & N/A & 0.002 & \begin{tabular}{|c|}
+393 \\
(positive \\
moderate)
\end{tabular} & $15.4 \%$ \\
\hline $\begin{array}{l}\text { 2. In comparison to } \\
\text { other children } \\
\text { his/her age, do you } \\
\text { think your child is } \\
\text { difficult to } \\
\text { understand? }\end{array}$ & 0.015 & \begin{tabular}{|c|}
+.319 \\
(positive \\
moderate)
\end{tabular} & $10.2 \%$ & 0.867 & 0.022 & $\mathrm{~N} / \mathrm{A}$ & 0.007 & \begin{tabular}{|c|}
+.353 \\
(positive \\
moderate)
\end{tabular} & $12.5 \%$ \\
\hline $\begin{array}{l}\text { 3. Do other people } \\
\text { think your child is } \\
\text { difficult to } \\
\text { understand? }\end{array}$ & 0.014 & \begin{tabular}{|c|}
+.320 \\
(positive \\
moderate)
\end{tabular} & $10.2 \%$ & 0.706 & 0.051 & N/A & 0.016 & \begin{tabular}{|c|}
+315 \\
(positive \\
moderate)
\end{tabular} & $9.9 \%$ \\
\hline $\begin{array}{l}\text { 4. Does your child } \\
\text { have difficulty } \\
\text { pronouncing words? }\end{array}$ & 0.123 & 0.205 & $\mathrm{~N} / \mathrm{A}$ & 0.574 & 0.075 & N/A & 0.422 & 0.108 & N/A \\
\hline $\begin{array}{l}\text { 5. Does your child } \\
\text { have problems } \\
\text { producing certain } \\
\text { sounds? }\end{array}$ & 0.018 & \begin{tabular}{|c|}
+313 \\
(positive \\
moderate)
\end{tabular} & $9.8 \%$ & 0.772 & 0.039 & N/A & 0.040 & $\begin{array}{c}+.273 \\
\text { (positive } \\
\text { weak) }\end{array}$ & $7.5 \%$ \\
\hline $\begin{array}{l}\text { 6. Does your child } \\
\text { leave out sounds } \\
\text { when he/she speaks? } \\
\text { For example, saying } \\
\text { "ca" for "cat", or } \\
\text { "tar" for "star?" }\end{array}$ & 0.003 & \begin{tabular}{|c|}
+392 \\
(positive \\
moderate)
\end{tabular} & $15.4 \%$ & 0.675 & 0.057 & $\mathrm{~N} / \mathrm{A}$ & 0.019 & \begin{tabular}{|c|}
+309 \\
(positive \\
moderate)
\end{tabular} & $9.5 \%$ \\
\hline $\begin{array}{l}\text { 7. Does you child } \\
\text { change sounds when } \\
\text { he/she speaks? For } \\
\text { example, saying } \\
\text { "too" for "shoe" or } \\
\text { "wun" for "run?" }\end{array}$ & 0.001 & \begin{tabular}{|c|}
+409 \\
(positive \\
moderate)
\end{tabular} & $16.7 \%$ & 0.437 & 0.104 & $\mathrm{~N} / \mathrm{A}$ & 0.004 & $\begin{array}{c}+.371 \\
\text { (positive } \\
\text { moderate) }\end{array}$ & $13.8 \%$ \\
\hline $\begin{array}{l}\text { 8. Is your child } \\
\text { frustrated when } \\
\text { he/she speaks? }\end{array}$ & 0.116 & 0.209 & $\mathrm{~N} / \mathrm{A}$ & 0.689 & 0.054 & N/A & 0.214 & 0.166 & $\mathrm{~N} / \mathrm{A}$ \\
\hline $\begin{array}{l}\text { 9. In comparison to } \\
\text { other children } \\
\text { his/her age, do you } \\
\text { think your child has } \\
\text { speech problems? }\end{array}$ & 0.081 & 0.231 & $\mathrm{~N} / \mathrm{A}$ & 0.964 & 0.006 & N/A & 0.124 & 0.205 & $\mathrm{~N} / \mathrm{A}$ \\
\hline $\begin{array}{l}\text { 10. Do other people } \\
\text { think your child has } \\
\text { speech problems? }\end{array}$ & not run & not run & $\begin{array}{l}\text { not } \\
\text { run }\end{array}$ & not run & $\begin{array}{l}\text { not } \\
\text { run }\end{array}$ & $\begin{array}{l}\text { not } \\
\text { run }\end{array}$ & not run & not run & $\begin{array}{l}\text { not } \\
\text { run }\end{array}$ \\
\hline
\end{tabular}

